\title{
GEOEKOLOŠKO VREDNOVANJE RELJEFA OTOKA HVARA $S$ ASPEKTA POLJODJELSKE VALORIZACIJE
}

\author{
Barbara Ruža Čirjak i Marica Mamut
}

\author{
Viterinci 4, Gornje Raštane \\ 23207 Sveti Filip i Jakov \\ e-mail: barbara.cirjak@gmail.com
}

Sažetak

Geoekološko vrednovanje reljefa otoka Hvara u svrhu razvoja poljodjelstva provedeno je metodom relativnog vrednovanja reljefa uz prilagodbe prema posebnostima istraživanog prostora $i$ korištenja. Vrednovanje je temeljeno na prethodnoj geomorfološkoj analizi $i$ analizi fizičke pogodnosti reljefa otoka (hipsometrija, vertikalna rašclanjenost, ekspozicija, stabilnost padina) te pogodnosti tla i dostupnosti pojedinih dijelova otoka za potrebe poljodjelskih aktivnosti.

Cilj provedenoga istraživanja bio je ustanoviti koji su dijelovi otoka Hvara pogodni ili potencijalno pogodni iz aspekta poljodjelstva. Dobiveni rezultati pokazali su da je samo $15 \%$ površine otoka Hvara pogodno za tržišno održivo poljodjelstvo. Agrarno najpovoljniji dio otoka Hvara je Hvarsko polje, zaravan Plame i pobrde Rudine-Kabal. Glavni ograničavajući faktor agrarne valorizacije pojedinih dijelova otoka Hvara su: nadmorka visina, velika vertikalna rašclanjenost te veliki nagibi koji povećavaju mobilnost padina. Prisutnost ovih ograničenja u agrarnom korištenju prostora osobito je istaknuto na središnjem dijelu grebena otoka Hvara koji je ocijenjen kao najnepogodniji prostor za agrarnu valorizaciju. Postojanje pogodnog tla ili prometnica ne može nadomjestiti nepogodnost terena koja proizlazi iz fizičkih karakteristika istog (nagibi, ekspozicija).

Ključne riječi: otok Hvar, geoekološko vrednovanje, metoda relativnog vrednovanja reljefa, poljodjelska valorizacija

\section{UVOD}

U prostornom planiranju danas sve veću ulogu imaju primijenjena geografska te geoekološka istraživanja zbog svojih prednosti u poznavanju prostornih sadržaja, procesa i odnosa. Jedan od najzastupljenijih aspekata geoekologije u prostornom planiranju je geoekološko vrednovanje (Mamut, 2010a, 2010b, 2010c). Putem geoekološkog vrednovanja, osim određivanja pogodnosti prostora za određeni način korištenja, stvara se i mogućnost otkrivanja nelogičnosti u korištenju prostora preko usporedbe dobivenih rezultata $s$ aktualnim načinom korištenja.

U radu se pristupa geoekološkom vrednovanju otoka Hvara (Slika 1) iz aspekta poljodjelstva kao dijela poljoprivrednog korištenja. Budući da različite poljodjelske kulture (npr. maslina i pšenica) imaju različite zahtjeve prema prostoru (vrsta i debljina tla, nagib padina, ekspozicija, temperatura, osunčanost, vlažnost tla, vlažnost zraka...), u 
radu nije analizirana pogodnost prostora za određene kulture, već mogućnost planiranja prostora za poljodjelsko iskorištavanje. Sukladno tome, nameće se potreba detaljnog interdisciplinarnog istraživanja u kojem bi sudjelovao veći broj znanstvenika i praktičara različitih polja i grana znanosti (agronomija, pedologija, geologija, agroklimatologija i sl). Krški prostor ne posjeduje mogućnost amortizacije velikih promjena u okolišnim odnosima te je potrebno vrlo malo neodgovornosti u gospodarenju njegovim resursima da bi se oni nepovratno izgubili. Gospodarenju krškim prostorom potrebno je pristupiti planski, posebno kada je riječ o agrarnoj valorizaciji krškog prostora i prirodnih resursa budući da je poljodjelstvo neraskidivo vezano uz iskorištavanje prirodne osnove.

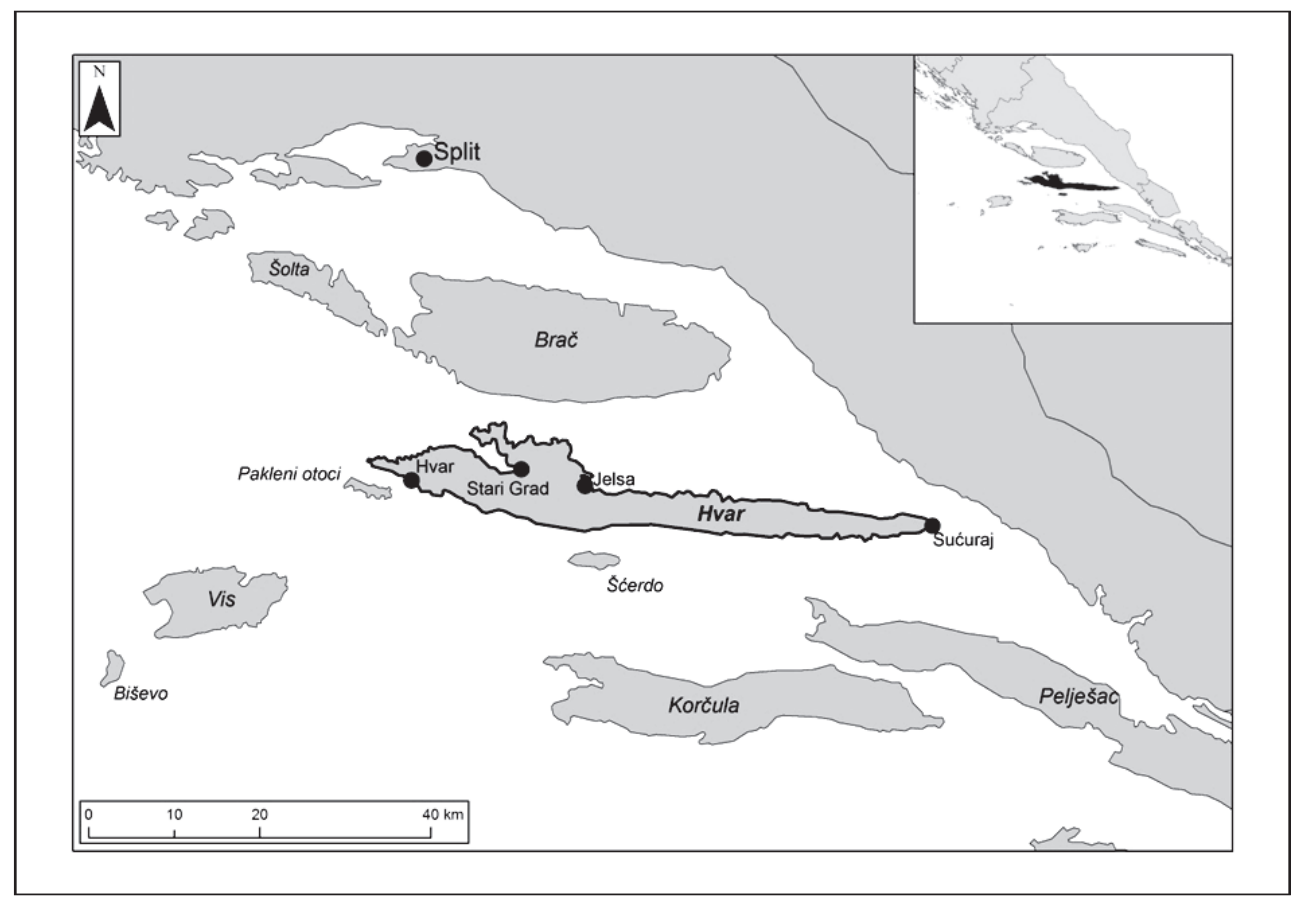

Slika 1. Geografski položaj otoka Hvara (Izradeno prema SRPJ, 2015)

Geoekološko vrednovanje reljefa nužno je započeti geomorfološkom analizom istraživanog prostora. Informacije koje dobivamo geomorfološkom analizom morfometrijskih i morfodinamskih obilježja reljefa određenog prostora krucijalne su za selekciju evaluacijskih kriterija u ljudskoj valorizaciji prostora (Saletto Janković, 1994). Za poljodjelsku valorizaciju otoka Hvara potrebno je utvrditi geomorfološki položaj otoka te analizirati morfografska obilježja njegova reljefa kako bi se prikazale glavne reljefne cjeline i njihove morfološke značajke. Morfometrijske (hipsometrija, nagibi, ekspozicija i vertikalna raščlanjenost padina) i morfodinamske (mobilnost padina) analize reljefa otoka, uz objašnjenje utjecaja na poljodjelsku valorizaciju, podrazumijevaju prikaz morfometrijskim kartama, geostatističku analizu i povezivanje morfostrukturnih elemenata. Pritom 
će hipsometrija, nagibi i mobilnost padina te vertikalna raščlanjenost biti temelj predvrednovanja, dok će ekspozicija padina biti jedan od elemenata vrednovanja u drugoj fazi geoekološke analize otoka Hvara iz aspekta poljodjelske valorizacije.

Inozemna geoekološka istraživanja i radovi su brojni, a nastali su kao odgovor na sve aktualnija pitanja degradacije i onečišćenja okoliša ${ }^{1}$ te njegove zaštite i očuvanja. Geoekologija, kao primijenjena znanost o krajoliku ${ }^{2}$ koji je okoliš čovjeka i drugih živih organizama, nudi praktična rješenja za sve veći broj problema u gospodarenju prostorom. Pritom se zadaci i ciljevi primijenjenih geoekoloških metoda (poznati kao LANDEP - Landscape Ecological Planing) i uključivanje geoekologije u praksu ostvaruju preko definiranja ekološki najoptimalnije prostorne organizacije, korišstenja i zaštite krajolika (Mamut, 2010c). Okoliš može biti pogodan, što znači da je za promatrani način korištenja on iskoristiv u svom trenutnom stanju (bez većih izmjena) ili potencijalno vrijedan prostor u kojem su potrebna poboljšanja ili izmjene da bi se zadovoljili zahtjevi za određenu ljudsku aktivnost (Mamut, 2010c). „Zadatak vrednovanja je definirati zahtjeve planiranog oblika korištenja te na temelju toga odrediti stupanj pogodnosti ili eventualna ograničenja vrednovanog prostora." (Mamut, 2010b:249-250).

Geoekološka istraživanja, unatoč svim koristima koje iz njih proizlaze, nisu u Republici Hrvatskoj česta i postoji mali broj dostupnih znanstvenih radova koji se bave geoekološkim vrednovanjem prostora iz aspekta pogodnosti istog za određeni način korištenja. Prvi rad s tematikom geoekološkog vrednovanja u Republici Hrvatskoj napisao je Bognar (1990). Važnost navedenog rada za ovo istraživanje proizlazi iz činjenice što oba rada istražuju isti prostor iz sličnih aspekata. Iako je ovaj rad tehnološki napredniji (npr. korištenje GIS-a) i utvrđuje pogodnost prostora za agrarno iskorištavanje, Bognarove spoznaje vezane za geomorfologiju otoka Hvara imaju veliko značenje i utjecaj na ovaj rad.

Nakon što je Bognar 1990. postavio temelje svojevrsnog geoekološkog vrednovanja, kroz iduća dva desetljeća javilo se nekoliko radova slične problematike koji su razradom korištenih metoda i vrednovanjem odabranih reljefnih oblika utjecali na ovaj rad. Osrečki (1994) je na temelju podrobnije obrade geomorfološke problematike istraživanog područja utvrdio usku povezanost reljefa kao prirodne datosti i turizma kao gospodarske grane. Saletto Janković (1994) je u radu izvršila geoekološko vrednovanje vrhova, kukova, eskarpmana, špilja, dolinskih dna i padina te prikazala „neophodnost uključivanja geomorfoloških istraživanja u svrhu cjelovitog upoznavanja osobina reljefa kao temeljnog elementa krajolika" (Saletto Janković, 1994:37). Šundov (2004) je u radu na temelju kartiranja i sustavnih geomorfoloških analiza prikazao geoekološko vrednovanje reljefa s aspekta njegove turističke valorizacije. Također, Mamut (2010a, b, c) je temeljem prethodno provedene geomorfološke analize reljefa odabranih prostora izvršila geoekološko vrednovanje iz tri aspekta: fizičke pogodnosti, estetske vrijednosti i

1 „U razlikovanju pojmova okoliš, okolina, okolica i hrvatskom jeziku još postoje određene nejasnoće. Često se okolina uzima kao pojam društvenog okruženja, okolica prirodnoga, a okoliš kao skupni naziv i za prirodno i za društveno čovjekovo okruženje." (Mamut, 2010a:261)

2 Izrazi „krajolik“ i „krajobraz“ su sinonimi. U ovom radu korišten je izraz „krajolik“, osim u slučajevima citiranja radova u kojima se koristi izraz „krajobraz“. 
dostupnosti pojedinih dijelova prostora za potrebe odabranih oblika rekreacije i turističkih aktivnosti - kupanja, sunčanja, šetnje, škrapinga. Geoekološko vrednovanje temeljilo se na Bognarovoj metodi relativnog vrednovanja reljefa kojom je prostor vrednovan u okviru četiri morfografske kategorije: padine, vrhovi, dolinska dna i korita te obale.

\section{CILJEVI I HIPOTEZE ISTRAŽIVANJA}

Cilj provedenog istraživanja je ustanoviti u kojoj su mjeri pojedini dijelovi otoka Hvara vrijedni ili potencijalno vrijedni iz aspekta poljodjelske valorizacije. Na stupanj pogodnosti ili eventualna ograničenja određene valorizacije prostora utječu prirodni i društveni elementi. Za poljodjelsku su valorizaciju povoljna područja niskih nadmorskih visina, malih nagiba, malih iznosa vertikalne raščlanjenosti, povoljne ekspozicije te područja koja obilježava stabilnost padina, agrarno iskoristivo tlo i prometna dostupnost (Crkvenčić i Malić, 1988). Otok Hvar karakterizira duga poljodjelska tradicija čiji su tragovi ostali „urezani“ u njegov krajolik još od vremena antike (Slika 2). Poljodjelska je djelatnost na otoku Hvaru koncentrirana uglavnom na Hvarskom polju, a poljodjelski je valorizirana i zaravan Plame (Magaš, 2013). Uzimajući u obzir ranije registrirane vidove (ne)korišstenja pojedinih dijelova krajolika otoka Hvara za poljodjelsku valorizaciju te prirodna i društvena obilježja, koja djeluju kao olakšavajući čimbenici za poljodjelsku valorizaciju (pomoću kojih se ocjenjuje stupanj pogodnosti ili eventualna ograničenja), postavljene su sljedeće hipoteze:

H1: Najveći dio otoka Hvara nije povoljan za poljodjelsku valorizaciju.

H2: Reljefna cjelina Hvarskog polja povoljna je za poljodjelsku valorizaciju zahvaljujući niskim nadmorskim visinama, malim nagibima, stabilnošću padina, malim iznosima vertikalne raščlanjenosti, povoljnom ekspozicijom, poljodjelski iskoristivim tlom te prometnom povezanošću.

H3: Zaravan Plame, koja je dio reljefne cjeline otočnog grebena, potencijalno je povoljna za poljodjelsku valorizaciju zahvaljujući malim nagibima padina i njihovom stabilnošću te ostalim povoljnim čimbenicima iz prirodne i antropogene sfere.

H4: Središnji dio otočnog grebena najnepovoljniji je dio otoka Hvara za poljodjelsku valorizaciju zbog recipročnosti karakteristika čimbenika navedenih u $\mathrm{H} 2$.

\section{METODOLOGIJA GEOEKOLOŠKOG VREDNOVANJA OTOKA HVARA S ASPEKTA POLJODJELSKE VALORIZACIJE}

$\mathrm{Na}$ postojanje i obavljanje određene djelatnosti u nekom prostoru utječu prirodna i društvena sfera, odnosno prilikom vrednovanja pozornost se mora posvetiti svim relevantnim elementima prostora. Pritom prirodni elementi krajolika, zbog specifičnosti poljodjelstva kao načina korištenja krajolika i djelatnosti, imaju veliku prevlast. U samom geoekološkom vrednovanju korišteni su reljef $i$ tlo čiji je stupanj pogodnosti jedan od uspjeha poljodjelstva. Geoekološko vrednovanje krajolika otoka Hvara iz aspekta poljodjelske valorizacije temelji se na metodi relativnog vrednovanja reljefa (Bognar, 1990). 


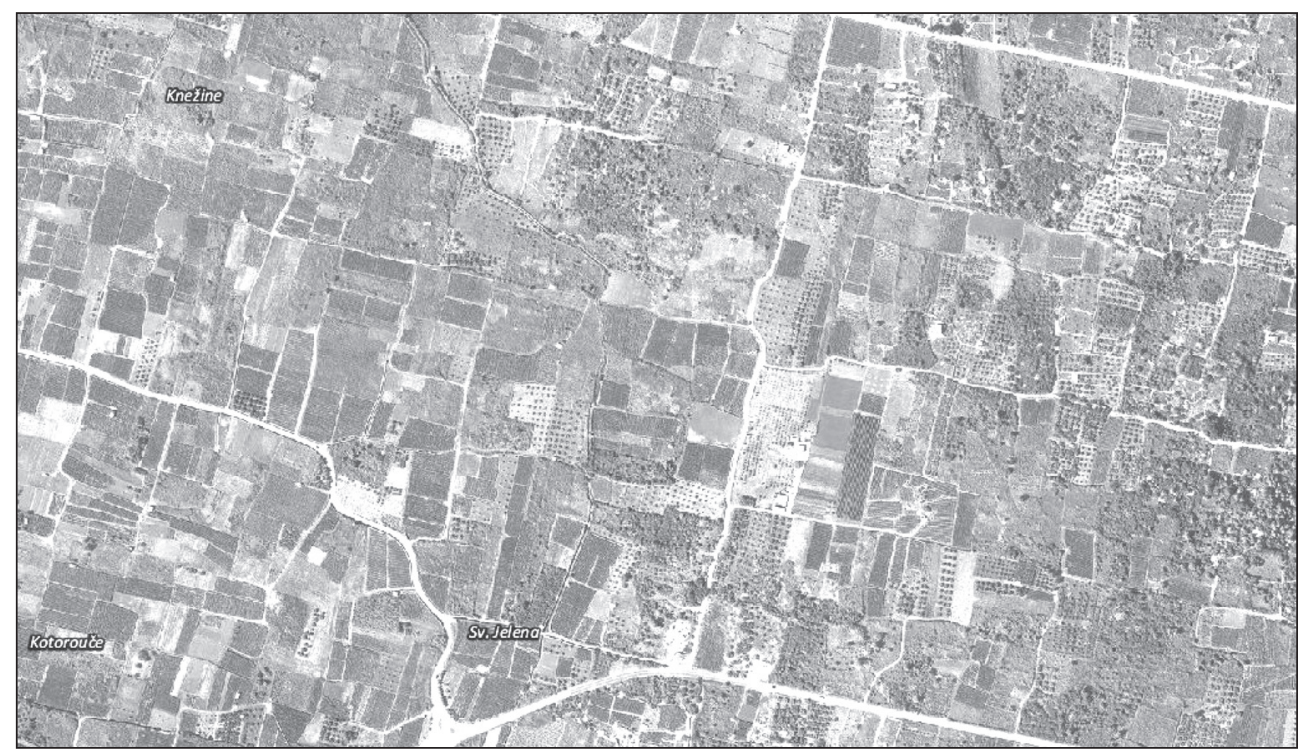

\section{Slika 2. Digitalni ortofoto snimak središnjeg dijela Hvarskog polja ukazuje na antičku} parcelizaciju (Izvor: SRPJ, 2015.)

Time se ocijenila pogodnost reljefa otoka Hvara uzevši u obzir njegove fizičke pogodnosti za poljodjelstvo na temelju padina. Padine se definiraju kao reljefne plohe određene hipsometrijskim razredima, nagibom u odnosu prema horizontalnoj površini te orijentacijom prema stranama svijeta čiji je recentni oblik posljedica utjecaja niza prirodnih i društvenih čimbenika tijekom geneze i evolucije reljefa. Analiza tala otoka Hvara provedena je razmatrajući njihova svojstva, obilježja te korisnost u poljodjelstvu (proizvodnog potencijala), ali i s aspekta njihove prostorne distribucije koja ovisi o brojnim zakonitostima i faktorima. Od društvenih elemenata odabrane su prometnice u smislu tipom (kvalitetom) uvjetovane dostupnosti. Tip, stanje ili (ne)postojanje prometnica određuju $s$ jedne strane i u određenoj mjeri uspješnost (iz tehničkog aspekta) obavljanja širokog spektra djelatnosti u nekom prostoru, dok s druge strane utječu na mogućnost i efikasnost prijevoza (distribucije) proizvedenih dobara. Eventualni negativni utjecaj prometnica zbog narušavanja stabilnosti padina nisu zabilježeni kao ograničavajući faktori razvoja poljodjelstva na vrednovanom prostoru.

Stoga je prije samog geoekološkog vrednovanja provedena morfografska analiza i analiza morfometrijskih parametara reljefa otoka Hvara iz aspekta njihove uloge u poljodjelskoj valorizaciji (hipsometrija, nagibi padina s mobilnošću padina, vertikalna raščlanjenost te ekspozicija padina) ${ }^{3}$ te pedološka analiza ${ }^{4} \mathrm{i}$ analiza prometnica u GIS okružju (ESRI

3 Hipsometrijska karta otoka Hvara izrađena je jednostavnom operacijom klasifikacije uz pomoć koje su pojedinačne ćelije rasterskog digitalnog modela reljefa klasificirane u hipsometrijske razrede označene različitim bojama. Karta nagiba padina otoka Hvara izrađena je pomoću funkcije Slope, karta vertikalne 
ArcGIS 10.1) na temelju rasterskog digitalnog modela reljefa prostorne rezolucije 50x50 m. Kao predložak za njegovu izradu korišten je NASA-in rasterski digitalni model reljefa SRTM (Shuttle Radar Topographic Mission) prostorne rezolucije 90x90 m (CGIAR Konzorcij za Prostorne Informacije, 2008) nakon čega mu je korištenjem alata Resample (bilinearna interpolacija novonastalih, tj. interpoliranih ćelija) prostorna rezolucija promijenjena na $50 \times 50 \mathrm{~m}$. Preuzeti digitalni model reljefa izvorno je u koordinatnom geografskom sustavu WGS84. Digitalni model reljefa otoka Hvara izdvojen je iz ostatka južne Hrvatske uz pomoć poligona otoka Hvara koji je sastavni dio slojeva „otoci“ u Središnjem registru prostornih jedinica (SRPJ). Iz spomenutog registra korišteni su još slojevi „otoci“, „Jadransko more“, „naselja“ (Slika 1) te slojevi „prometnice“.

Samo geoekološko vrednovanje krajolika temelji se na bodovanju ovisno o tome u kojoj se kategoriji određenog prirodnog elementa ili elementa društvene nadgradnje promatrano područje nalazi. Ukoliko se ocijeni da na nekom području obilježje prirodnog elementa ili elementa društvene nadgradnje krajolika pozitivno utječe na razvoj određenog načina korištenja zemljišta tog područja, tada se na temelju tog obilježja elementa krajolika vrednovanom području dodjeljuje određen broj bodova. Broj bodova je veći što je pozitivniji utjecaj elementa krajolika tj. korištenja istog, odnosno manji ako je utjecaj elementa negativan. Ukoliko je negativan utjecaj intenzivniji, dodijeljen je negativan broj bodova. Bodovi se dodjeljuju jediničnim površinama čije se dimenzije i položaj određuju izračunom (Mamut, 2010a, 2010b, 2010c). Za ovo geoekološko vrednovanje odabrana je mreža kvadratičnih jediničnih površina ${ }^{5}$ dimenzija 500x500 metara (1x1 cm na karti mjerila 1:50 000) (Mamut, 1999). Dodjeljivanje bodova vrši se usporedbom mreže jediničnih površina tematskih karata. Sve operacije geoekološkog vrednovanja, kao i izrada kartografskih prikaza, izvršene su u GIS okružju (ESRI ArcGIS 10.1).

\section{GEOMORFOLOŠKI POLOŽAJ OTOKA HVARA}

Geomorfološku regionalizaciju Hrvatske ${ }^{6}$ izradio je A. Bognar (2001). Iz geotektonskog aspekta, otok Hvar pripada zoni Vanjskih Dinarida za koje je karakteristična borano-rasjedno-ljuskava geološka struktura (Bognar, 2001; Džaja, 2003). Otok Hvar pripada

raščlanjenosti reljefa pomoću funkcije Focal Statistics, a karta ekspozicije padina pomoću funkcije Aspect. 4 Pedološka je karta izrađena manualnom digitalizacijom na temelju Digitalne pedološke karte Republike Hrvatske izrađene od strane Zavoda za kemiju, biologiju i fiziku tla Poljoprivrednog fakulteta Sveučilišta Josipa Jurja Strossmayera u Osijeku. Navedena digitalna pedološka karta Hrvatske nastala je na temelju Namjenske pedološke karte Republike Hrvatske u mjerilu 1:300 000, tako da su boje na karti odabrane prema tumaču iste (Digitalna pedološka karta RH, 2014).

5 Mreža jediničnih površina, koja je temelj geoekološkog vrednovanja krajolika otoka Hvara iz aspekta poljodjelske valorizacije, napravljena je pomoću funkcije Create Fishnet te pomoću funkcije Clip izrezana da odgovara prostornom obuhvatu otoka Hvara.

6 Temelj za izdvajanje geomorfoloških regija su morfostrukturne, morfogenetske, litološke i orografske reljefne datosti. Bognar (2001), za prostor Hrvatske, razlikuje osam hijerarhijskih taksonomskih jedinica, od najniže razine prema najvišoj: morfofacijesi, morfofacijesne grupe, mikrogeomorfološke, subgeomorfološke, mezogeomorfološke, makrogeomorfološke i megageomorfološke regije te morfogenetski sustavi. 
megageomorfološkoj regiji Gorskog sustava Dinarida (2.) koja je izdvojena na temelju značajki strukturno geomorfološke evolucije unutar morfogenetskog sustava. Na sljedećem nižem hijerarhijskom stupnju, otok Hvar pripada makrogeomorfološkoj regiji Centralne Dalmacije s arhipelagom (2.4.) koja je velika morfostrukturna regionalna cjelina čiji je opći geomorfološki razvoj i dinamika, morfoevolucijski gledano kroz duže vrijeme, jedinstven. Svaka makrogeomorfološka regija sastoji se od morfogenetski sličnih mezogeomorfoloških regija na nižoj razini. Otok Hvar dio je Centralnodalmatinskog arhipelaga (2.4.4.) koji je kao mezogeomorfološka regija izdvojen na temelju svojih hidro-orografskih, morfoevolucijskih i geoloških datosti. Na najnižoj razini regionalizacije otok Hvar sa svojim arhipelagom čini vlastitu subgeomorfološku regiju (2.4.4.3.) $s$ arhipelagom koja je geomorfološki istovrsna $s$ ostalim subgeomorfološkim regijama mezogeomorfološke regije Centralnodalmatinskog arhipelaga te je s njima morfoevolucijski povezana. Od njih se razlikuje zbog vlastitih morfofacijesnih grupa koje su neovisnijih značajki u strukturnom i orografskom smislu (Bognar, 2001).

\section{MORFOGRAFSKA OBILJEŽJA RELJEFA OTOKA HVARA}

Prema Bognaru (1990), otok Hvar čine tri velike reljefne cjeline koje su iz morfostrukturnog aspekta antiklinale. To su hrbat otoka, Hvarsko polje te pobrđe Rudine-Kabal (Slika 3).

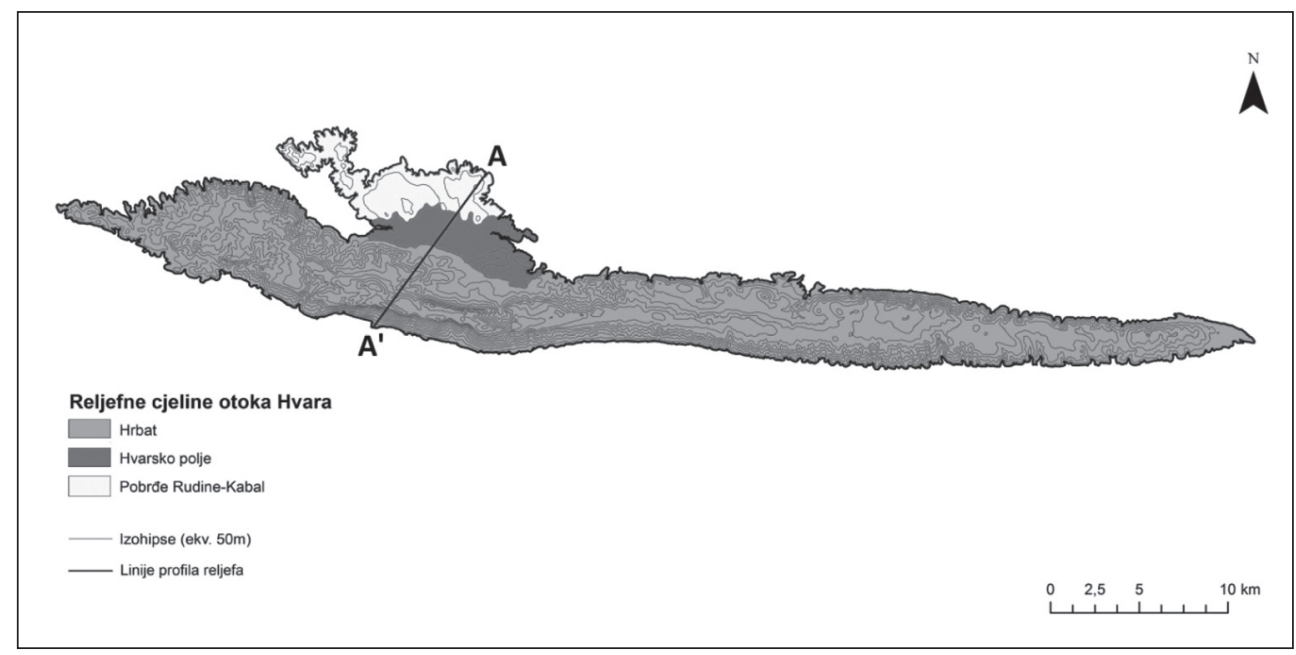

Slika 3. Morfografska karta otoka Hvara (Izradeno prema SRPJ, 2015; CGIAR Konzorcij za prostorne Informacije, 2008; podjela reljefnih cjelina, prema: Bognar, 1990)

Otočni hrbat (Slika 3) nastao je emerzijom dijela mezozojske karbonatne platforme pod utjecajem stresa proizvedenog laramijskom i pirenejskom fazom alpske orogeneze, odnosno kolizijom afričke i euroazijske ploče (Herak, 1991, 1999). Reljef hrpta je konforman što znači da se podudara sa morfostrukturom hrpta koji je antiklinala dugačka preko 60 kilometara (Bognar, 1990). 
Pobrđe Rudine-Kabal (Slika 3) dio je stare i široke denudacijske zaravni koja je neotektonskim pokretima u srednjem miocenu razlomljena, a njeni dijelovi izdignuti odnosno spušteni. Reljef pobrđa je konforman. Pobrđe je u prošlosti bilo zaravnjavano intenzivnim korozijskim, padinskim te fluvijalnim procesima (Bognar, 1990).

Hvarsko se polje nalazi u središnjem zapadnom dijelu otoka (Slika 3). Budući da se reljefni sklop ne podudara s morfostrukturnim sklopom, Hvarsko polje ima karakteristiku diskonformnosti reljefa, odnosno reljefne inverznosti. Hvarsko polje je blaga depresija nastala denudacijom sekundarne otočne antiklinale Stari Grad-Vrboska. Denudacija se odvila pod utjecajem korozijskih, padinskih te fluvijalnih procesa čemu svjedoče fluvijalni sedimenti te sedimenti materijala nastalog padinskim procesima (Bognar, 1990). Zajedno s hrbatskom zaravni (zaravan Plame) u području Gdinja te niskim pobrđem Rudine-Kabal, Hvarsko je polje također dio vrlo starog i vrlo širokog denudacijskog nivoa koji je nastao otprilike između kraja pirenejske faze alpske orogeneze u eocenu te neotektonskih pokreta u srednjem miocenu. Ta je široka denudacijska zaravan neotektonskim pokretima bila razdrobljena te su neki blokovi potonuli, a neki se izdigli (Bognar, 1990).

Profil A-A' (Slika 4) siječe sve tri reljefne cjeline otoka Hvara te pokazuje odnos visina otočnog hrpta te Hvarskog polja kojem se najveći dio visina nalazi ispod 50 metara nadmorske visine što pokazuje da je Hvarsko polje najniži dio otoka Hvara.

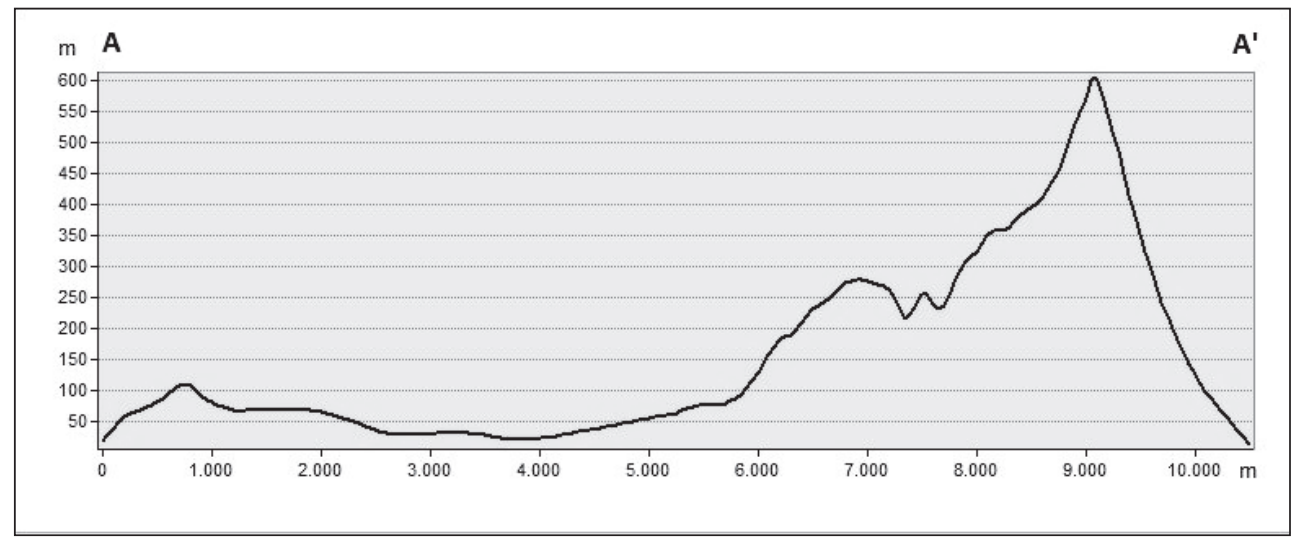

Slika 4. Profil A - A' (Izradeno prema CGIAR Konzorcij za Prostorne Informacije, 2008)

\section{MORFOMETRIJSKA OBILJEŽJA RELJEFA OTOKA HVARA ANALIZA HIPSOMETRIJE}

$\mathrm{Za}$ potrebe geoekološkog vrednovanja iz aspekta poljodjelske valorizacije, na otoku Hvaru izdvojeno je 6 visinskih razreda od 0-100, 100-200, 200-300, 300-400, 400500 te razred koji obuhvaća visine iznad 500 metara. Analiza hipsometrije pokazuje da visine na otoku Hvaru rastu zonalno od obale prema unutrašnjosti. Specifična prostorna distribucija visinskih razreda na otoku Hvaru posljedica je djelovanja endogenih i egzogenih sila i procesa, odnosno morfostrukture i morfogeneze otoka. 
Apsolutno površinom, a time i relativnim udjelom u ukupnoj površini otoka najzastupljenija visinska kategorija je od 0 do 100 metara nadmorske visine na koju otpada 116,49 $\mathrm{km}^{2}$, odnosno 39,11\% površine (Tablica 1). Navedena kategorija odnosi se na uske obalne prostore reljefne cjeline otočnog hrpta (Slika 5) te na reljefne cjeline Hvarskog polja te pobrđa Rudine-Kabal koje samo mjestimice izbija iznad izohipse od 100 metara nadmorske visine (Slika 3, Slika 5). Antiklinale Hvarskog polja i pobrđa Rudine-Kabal obilježava najniža hipsometrijska kategorija jer su tijekom geološke prošlosti bile zaravnjavane korozijskim, fluvijalnim te padinskim procesima. Hrbat je glavna otočna antiklinala nastala emerzijom iz mezozojske karbonatne platforme koju i danas karakterizira živa tektonika i izdizanje (Bognar, 1990). Najviše hipsometrijske kategorije, od 400-500m te $>500 \mathrm{~m}$ obilježje su centralnog zapadnog dijela otočnog hrpta (Slika 5), a zauzimaju najmanju površinu otoka - 11,7 $\mathrm{km}^{2}$ (Tablica 1). Visine hrpta opadaju od središnjeg zapadnog dijela prema istoku i zapadu ulazeći postupno u hipsometrijske kategorije 300-400, 200-300, 100-200 te 0-100 metara u obalnom prostoru. Jedina iznimka postupnom opadanju visina od središnjeg zapadnog dijela hrpta prema rubovima je otočno uzvišenje (zaravan Plame) u hipsometrijskoj kategoriji od 300-400 metara u istočnom dijelu otoka (Tablica 1, Slika 5).

Tablica 1. Visinski razredi reljefa otoka Hvara s površinama i udjelima u ukupnoj površini

\begin{tabular}{|c|c|c|}
\hline Visinski razredi (m) & Površina $\left.\mathbf{( k m}^{\mathbf{}}\right)$ & Udio u ukupnoj površini (\%) \\
\hline $0-100$ & 116,49 & 39,11 \\
\hline $100-200$ & 73,61 & 24,71 \\
\hline $200-300$ & 57,67 & 19,36 \\
\hline $300-400$ & 39,39 & 12,89 \\
\hline $400-500$ & 9,02 & 3,03 \\
\hline$>500$ & 2,68 & 0,9 \\
\hline Ukupno & 297,86 & 100 \\
\hline
\end{tabular}

Izvor: Izradeno prema atributnoj tablici hipsometrijske karte (Slika 5)

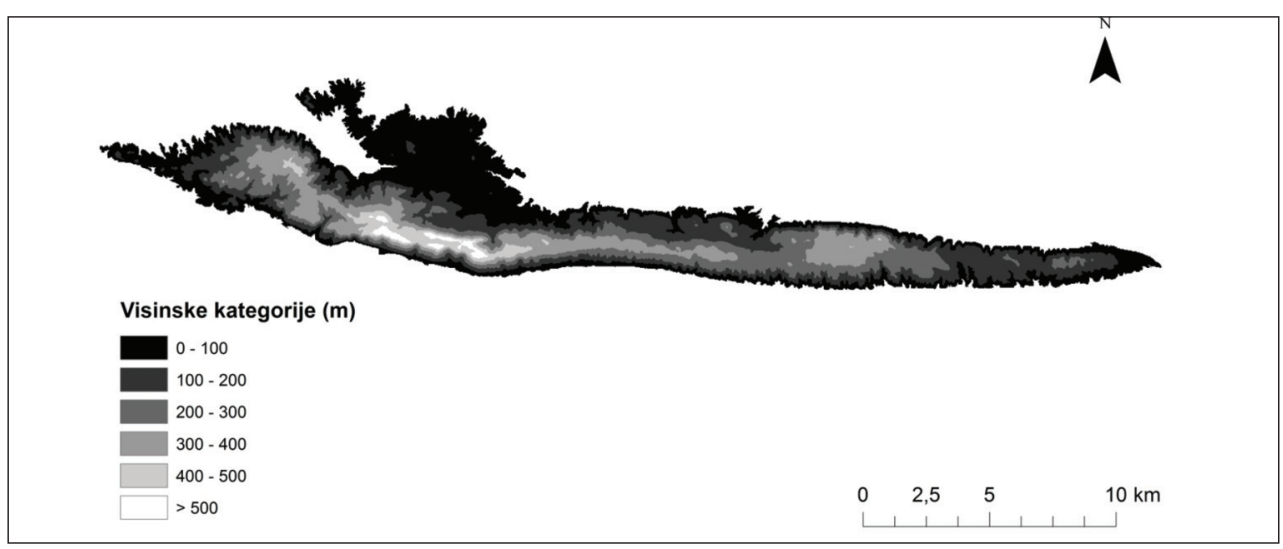

Slika 5. Hipsometrijska karta otoka Hvara (Izradeno prema CGIAR Konzorcij za Prostorne Informacije, 2008) 


\section{ANALIZA NAGIBA I MOBILNOSTI PADINA}

U prostornoj distribuciji različitih kategorija nagiba padina ocrtava se duboka povezanost sa morfostrukturom i morfogenezom otoka Hvara. Prve dvije kategorija nagiba $\left(0-2^{\circ}, 2-5^{\circ}\right)$ zauzimaju $23,22 \%$ površine otoka (Tablica 2$)$, a zastupljene su u reljefnim cjelinama Hvarsko polje i pobrde Rudine-Kabal (Slika 3) te u zaravni Plame (Slika 6, Slika 8). Zaravan Plame je zajedno sa Hvarskim poljem i pobrđem Rudine-Kabal bila dio starog i širokog denudacijskog nivoa, a navedena područja su tijekom geološke prošlosti bila denudirana korozijskim, fluvijalnim i padinskim procesima (Bognar, 1990). Jedino su primorske padine pobrđa Rudine-Kabal te kontaktne padine zaravni Plame sa sjevernom i južnom fasadom otočnog hrpta obilježene nešto većim nagibima - onim od $5-12^{\circ}$ (Slika 6$)$.

Tablica 2. Kategorije nagiba padina otoka Hvara s površinama i udjelima u ukupnoj pouršini

\begin{tabular}{|c|c|c|}
\hline Kategorije nagiba $\left(^{\circ}\right)$ & Površina $\left(\mathbf{k m}^{\mathbf{}}\right)$ & Udio u ukupnoj površini (\%) \\
\hline $0-2$ & 21,68 & 7,28 \\
\hline $2-5$ & 47,49 & 15,94 \\
\hline $5-12$ & 99,52 & 33,41 \\
\hline $12-32$ & 124,3 & 41,73 \\
\hline$>32$ & 4,87 & 1,63 \\
\hline Ukupno & 297,86 & 100 \\
\hline
\end{tabular}

Izvor: Izradeno prema atributnoj tablici karte nagiba otoka Hvara (Slika 6)

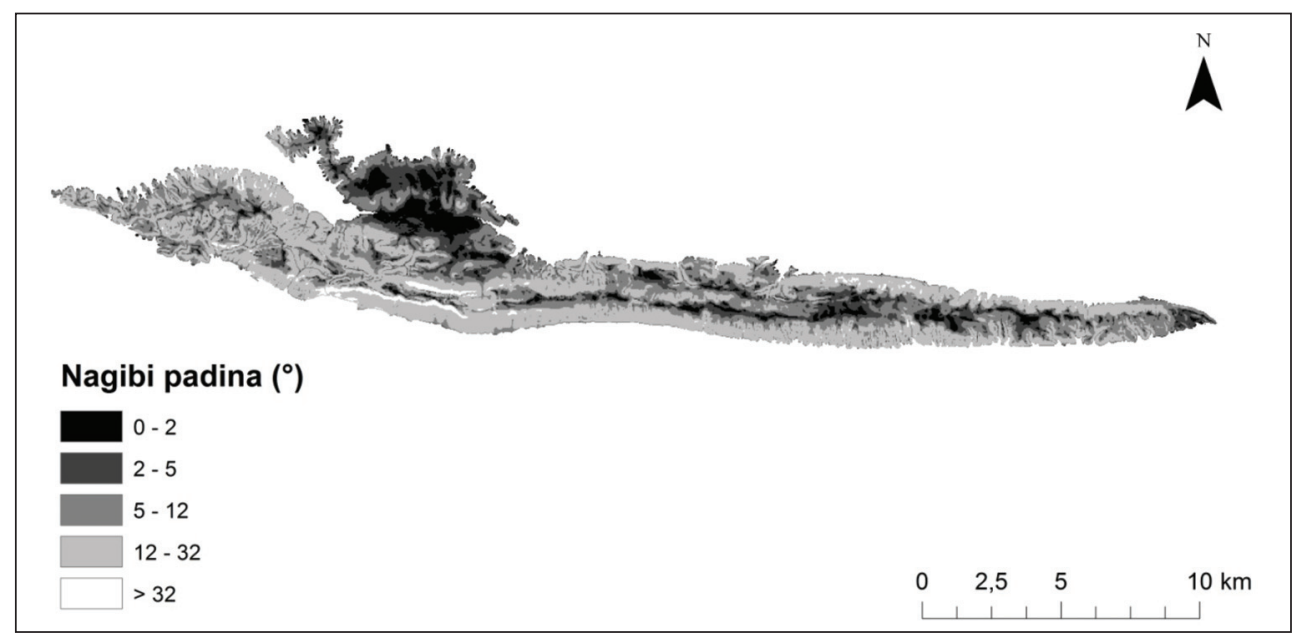

Slika 6. Karta nagiba padina otoka Hvara (Izradeno prema CGIAR Konzorcij za Prostorne Informacije, 2008) 
Padine sjeverne i južne fasade otočnog hrpta obilježene su nagibima u kategoriji od $12-32^{\circ}$ (Slika 6). Padine obuhvaćene posljednjom kategorijom nagiba, $>32^{\circ}$ (do $46^{\circ}$ ) obilježje su najviših zona središnjeg dijela otočnog hrpta na zapadnoj polovici otoka. Jedna od specifičnosti u prostornom rasporedu različitih kategorija nagiba je zastupljenost kategorija vrlo malih nagiba u samom središnjem dijelu hrpta. Nagibi od $0-2^{\circ}$ i $2-5^{\circ}$ imaju otočni karakter pojavljivanja, a okruženi su nagibima od $5-12^{\circ}$ (Slika 6). Navedeno sugerira da se tu radi o sistemu plitkih depresija okruženih sjevernim i južnim grebenom otočnog hrpta.

Nagib padina usko je povezan s padinskim procesima koji se na njima javljaju, odnosno o iznosu nagiba ovisi ravnotežno stanje padine i materijala koji se na njoj nalazi (Tablica 3). Veza između nagiba padine i padinskih procesa koji se na njoj javljaju temelji se na činjenici da će veći nagib padine uvjetovati veći intenzitet padinskih procesa, odnosno veći intenzitet njihove destrukcijske moći. Samim time, ravnotežno stanje padina kreće se od stabilnog prema mobilnom s povećanjem nagiba padine (Bognar, 1990; Summerfield, 1991; Mamut, 2010b).

Tablica 3. Mobilnost padina otoka Hvara

\begin{tabular}{|c|c|c|c|}
\hline $\begin{array}{c}\text { Kategorije } \\
\left.\text { nagiba } \mathbf{(}^{\circ}\right)\end{array}$ & $\begin{array}{c}\text { Naziv nagnute } \\
\text { površine }\end{array}$ & $\begin{array}{c}\text { Ravnotežno } \\
\text { stanje }\end{array}$ & Dominantni padinski procesi \\
\hline $0-2$ & ravnice & stabilno & $\begin{array}{c}\text { nema vidljivih tragova kretanja, } \\
\text { spiranje je minimalno }\end{array}$ \\
\hline $2-5$ & $\begin{array}{c}\text { blago nagnuti } \\
\text { teren }\end{array}$ & $\begin{array}{c}\text { potencijalno } \\
\text { mobilno }\end{array}$ & $\begin{array}{c}\text { vidljivi tragovi kretanja, izraženo } \\
\text { spiranje i puženje tla }\end{array}$ \\
\hline $5-12$ & nagnuti teren & $\begin{array}{c}\text { potencijalno } \\
\text { mobilno }\end{array}$ & $\begin{array}{c}\text { jača erozija, intenzivno spiranje, } \\
\text { puženje, tečenje i kliženje tla }\end{array}$ \\
\hline $12-32$ & $\begin{array}{c}\text { znatno nagnuti } \\
\text { teren }\end{array}$ & mobilno & $\begin{array}{c}\text { veoma snažna erozija, puženje, tečenje } \\
\text { i kliženje tla }\end{array}$ \\
\hline $32-55$ & $\begin{array}{c}\text { veoma strme } \\
\text { padine }\end{array}$ & mobilno & $\begin{array}{c}\text { odnošenje materijala, kliženje tla i } \\
\text { urušavanje stijenskih blokova }\end{array}$ \\
\hline$>55$ & strmci, litice & mobilno & $\begin{array}{c}\text { dominira urušno gravitacijsko kretanje } \\
\text { materijala, odroni }\end{array}$ \\
\hline
\end{tabular}

Izvor: Bognar, 1990; Summerfield, 1991; Mamut, 20106

Veći nagibi uvjetuju tehničke poteškoće u obradi zemlje, povećava se podložnost eroziji, spiranju tla i hranjivih tvari te se smanjuje infiltracija vode u podzemlje, a sve navedeno u velikoj mjeri smanjuje produktivnost tla. Porastom nagiba padine mora se puno više paziti i na održivost korištenja jer se neadekvatnim korištenjem padine velikog nagiba smanjuje i dugoročna pogodnost za poljodjelstvo. Ipak, pravilnim korištenjem i rukovanjem prilikom obrade zemlje na dugoročnost i održivost korištenja može se u određenoj mjeri utjecati. Jedne od najvećih grešaka prilikom obrade zemljišta na padini velikog nagiba su oranje u pravcu pružanja padine te neodgovarajuća dubina oranja. Takav neodgovoran način korištenja povećava podložnost padine eroziji vodom budući 
da je površinsko otjecanje vode usmjereno duž brazdi. Adekvatno oranje bilo bi ono u smjeru okomito na pravac pružanja padine čime bi se erozija padine vodom smanjila (Crkvenčić i Malić, 1988).

\section{ANALIZA VERTIKALNE RAŠČLANJENOSTI}

Vertikalna raščlanjenost kvantitativni je indikator geomorfoloških osobina i procesa koji se odvijaju u reljefu te je izraz morfostrukturnih i morfogenetskih osobina reljefa. U područjima s većom vertikalnom raščlanjenošću intenzitet erozije tla je veći, dakle prevladava odnošenje materijala. $S$ druge strane, u područjima s manjom vertikalnom raščlanjenošću prevladava akumulacija materijala (Lozić, 1995). Koreliranjem karte vertikalne raščlanjenosti (Slika 7) s kartom nagiba padina (Slika 6), moguće je odrediti površine koje imaju manju ili veću iskoristivost za poljodjelstvo. Drugim riječima, analiza vertikalne raščlanjenosti reljefa doprinosi identifikaciji zemljišta povoljnog iz aspekta stabilnosti i ravnoteže padina po pitanju erozivnih i padinskih procesa.

Standardno se izdvaja 6 kategorija vertikalne raščlanjenosti: 0-5, 5-30, 30-100, 100300, 300-800 te $>800 \mathrm{~m} / \mathrm{km}^{2}$ (Gams i sur., 1981; Bognar, 1992, preuzeto iz: Lozić, 1995). GIS analiza 50-metarskog digitalnog modela reljefa prepoznala je iznos od 7 $\mathrm{m} / \mathrm{km}^{2}$ kao najmanji, što znači da na otoku Hvaru ne postoji dio reljefa koji spada u kategoriju od 0-5 m/ $\mathrm{km}^{2}$, odnosno na otoku Hvaru s aspekta vertikalne raščlanjenosti ne postoji zaravnjen reljef. Navedena činjenica nije rezultat relativne generaliziranosti koja je proizvod korištenja 50-metarskog digitalnog modela reljefa jer i Bognar (1990) u svojoj detaljnoj geomorfološkoj analizi reljefa otoka Hvara navodi samo da je prisutna vertikalna raščlanjenost reljefa i ispod $10 \mathrm{~m} / \mathrm{km}^{2}$, ali ne navodi postojanje kategorije od $0-5 \mathrm{~m} / \mathrm{km}^{2}$. Također, na otoku Hvaru nije prisutna posljednja kategorija $\left(>800 \mathrm{~m} / \mathrm{km}^{2}\right)$. $\mathrm{Na}$ otoku Hvaru, najveći iznos vertikalne raščlanjenosti reljefa je $587 \mathrm{~m} / \mathrm{km}^{2}$.

Tablica 4. Kategorije vertikalne rašclanjenosti reljefa otoka Hvara s površinama i udjelima u ukupnoj površini

\begin{tabular}{|c|c|c|c|}
\hline $\begin{array}{c}\text { Kategorije } \\
\text { vertikalne } \\
\text { raščlanjenosti } \\
\left(\mathbf{m} / \mathbf{k m}^{2}\right)\end{array}$ & Opis kategorije & $\begin{array}{c}\text { Površina } \\
\left.\mathbf{( k m}^{2}\right)\end{array}$ & $\begin{array}{c}\text { Udio u } \\
\text { ukupnoj } \\
\text { površini } \\
\mathbf{( \% )}\end{array}$ \\
\hline $7-30$ & slabo raščlanjene ravnice & 5,63 & 1,89 \\
\hline $30-100$ & slabo raščlanjen reljef & 61,78 & 20,74 \\
\hline $100-300$ & umjereno raščlanjen reljef & 201,15 & 67,53 \\
\hline$>300$ & izrazito raščlanjen reljef & 29,31 & 9,84 \\
\hline Ukupno & - & 297,86 & 100 \\
\hline
\end{tabular}

Izvor: atributna tablica karte vertikalne rašclanjenosti (Slika 7); opis kategorija: Bognar, 1990. 


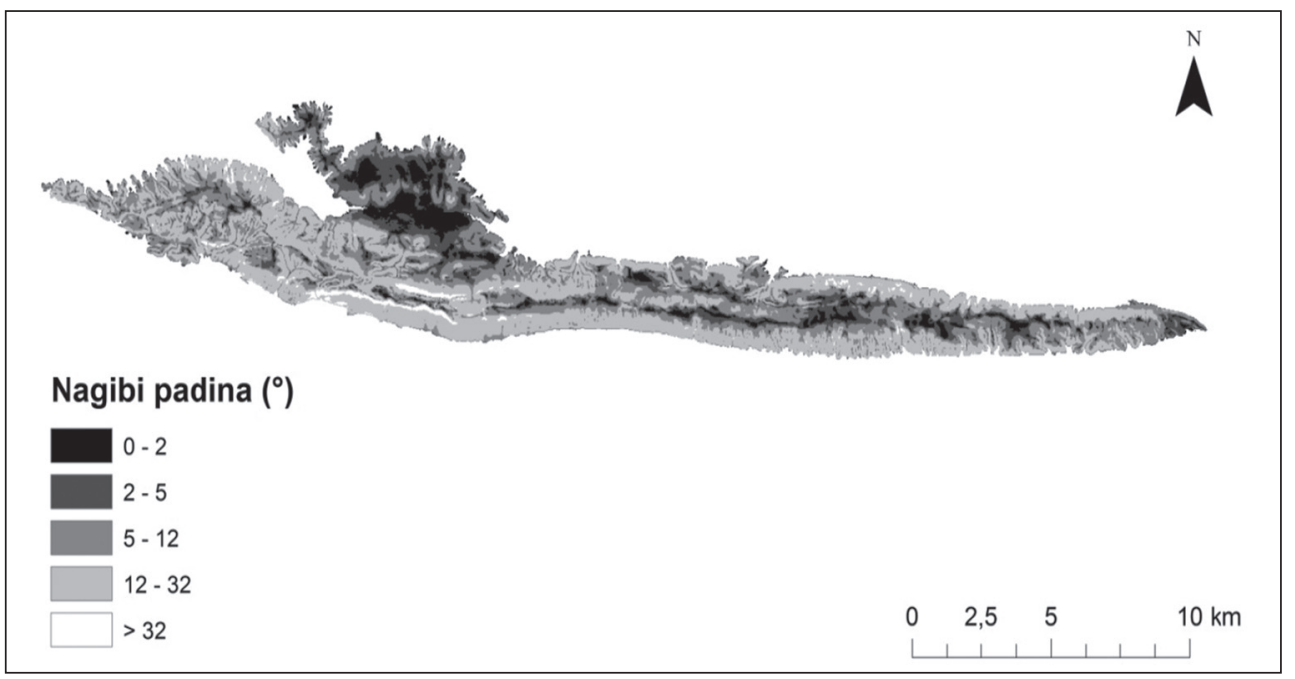

Slika 7. Karta vertikalne rašclanjenosti reljefa otoka Hvara (Izradeno prema CGIAR Konzorcij za Prostorne Informacije, 2008)

Najzastupljenija kategorija vertikalne raščlanjenosti reljefa na otoku Hvaru je od 100$300 \mathrm{~m} / \mathrm{km}^{2}$ (umjereno rašclanjen reljef), a karakterizira 67,53\% površine otoka Hvara (Tablica 4). Ona obilježava reljefnu cjelinu hrpta otoka Hvara. Najviše vrijednosti vertikalne raščlanjenosti reljefa, one iznad $300 \mathrm{~m} / \mathrm{km}^{2}$ (izrazito raščlanjen reljef), obilježje su samog centralnog dijela zapadne polovice hrpta gdje on doseže i najveće visine (Slika 7). Dokaz za vrlo aktivnu tektoniku su brojne duboke usječene doline tekućica (neke preko 100 metara duboke), a koje danas više ne postoje (Bognar, 1990). Usporedbom profila reljefa te karte nagiba (Slika 6) lako se može vidjeti da su sjeverna te južna fasada hrpta, koje su ujedno i krila antiklinale, obilježene diseciranim padinama velikih nagiba što je također jedan od pokazatelja vrlo aktivnog izdizanja i tektonike. Kategorija vertikalne rašllanjenosti od $7-30 \mathrm{~m} / \mathrm{km}^{2}$, odnosno slabo raščlanjene ravnice, javlja se $\mathrm{u}$ središtu Hvarskog polja, te u zaravnjenim područjima pobrđa Rudine-Kabal. Najveći dio pobrđa Rudine-Kabal, veći dio Hvarskog polja i zaravni Plame obilježeni su kategorijom vertikalne raščlanjenosti od $30-100 \mathrm{~m} / \mathrm{km}^{2}$, odnosno slabo raščlanjenim reljefom. Izuzetak su rubni dijelovi pobrđa obilježeni kategorijom vertikalne raščlanjenosti od $100-300 \mathrm{~m} / \mathrm{km}^{2}$ (Slika 7).

\section{ANALIZA EKSPOZICIJE PADINA}

Prema ekspoziciji, padine je moguće grupirati u tople / prisojne i hladne / osojne. Tople / prisojne su J, JZ, te JI padine, dok su hladne / osojne S, SI, te SZ padine. Također se izdvaja i kategorija bez ekspozicije koja obuhvaća padine koje nemaju izraženu orijentaciju (horizontalne padine i padine vrlo malih nagiba) (Pahernik, 2007). Ekspozicija padina utječe na pojavu i intenzitet geomorfoloških i padinskih procesa. Izloženost ja- 
koj kratkovalnoj dnevnoj sunčevoj radijaciji, odnosno orijentiranost prema toploj strani (JI, J, JZ), uvjetuje izloženost padina većim dnevnim i sezonskim amplitudama što opet rezultira pojačanim intenzitetom mehaničkog trošenja uvjetovanog termičkim širenjem i skupljanjem materijala (Lozić i sur., 2013).

Specifičnosti u udjelima pojedinih kategorija ekspozicije padina u ukupnoj površini otoka Hvara posljedica su njegovog pružanja. Otok Hvar ima dominantno pružanje u smjeru I-Z, a to pružanje prati najveća reljefna cjelina otoka - otočni hrbat. Zbog navedene specifične morfografije otoka Hvara najzastupljenije ekspozicije padina su sjeverna ( $20,17 \%$ površine otoka) te južna $(17,21 \%$ površine otoka) (Tablica 5$)$. Kada se grupiraju i zbroje udjeli hladnih / osojnih te toplih / prisojnih ekspozicija dolazi se do podatka da 45,15\% ukupne površine otoka obilježava hladna orijentacija. Nasuprot tome, topla orijentacija obilježava $39,4 \%$ površine otoka. Insolacijski neutralne istočne i zapadne ekspozicije imaju približno jednake udjele, a zajedno obilježavaju samo $15 \%$ padina otoka Hvara. Bez ekspozicije je zanemariva površina, svega $1 \mathrm{~km}^{2}(0,34 \%$ površine otoka) (Tablica 5, Slika 8).

Tablica 5. Kategorije ekspozicije padina otoka Hvara s površinama i udjelima u ukupnoj površini

\begin{tabular}{|l|c|c|c|}
\hline Ekspozicija padina & Azimut $\left(^{\circ}\right)$ & Površina $\mathbf{( k m}^{\mathbf{}} \mathbf{)}$ & Udio u ukupnoj površini (\%) \\
\hline Bez ekspozicije & - & 1,01 & 0,34 \\
\hline Sjeverna & $337-22$ & 60,1 & 20,17 \\
\hline Sjeveroistočna & $22-67$ & 42,1 & 14,14 \\
\hline Istočna & $67-112$ & 21,64 & 7,26 \\
\hline Jugoistočna & $112-157$ & 29,13 & 9,78 \\
\hline Južna & $157-202$ & 51,26 & 17,21 \\
\hline Jugozapadna & $202-247$ & 36,96 & 12,41 \\
\hline Zapadna & $247-292$ & 23,36 & 7,84 \\
\hline Sjeverozapadna & $292-337$ & 32,3 & 10,84 \\
\hline Ukupno & 360 & 297,86 & 100 \\
\hline
\end{tabular}

Izvor: Izradeno prema atributnoj tablici karte ekspozicije padina (Slika 8)

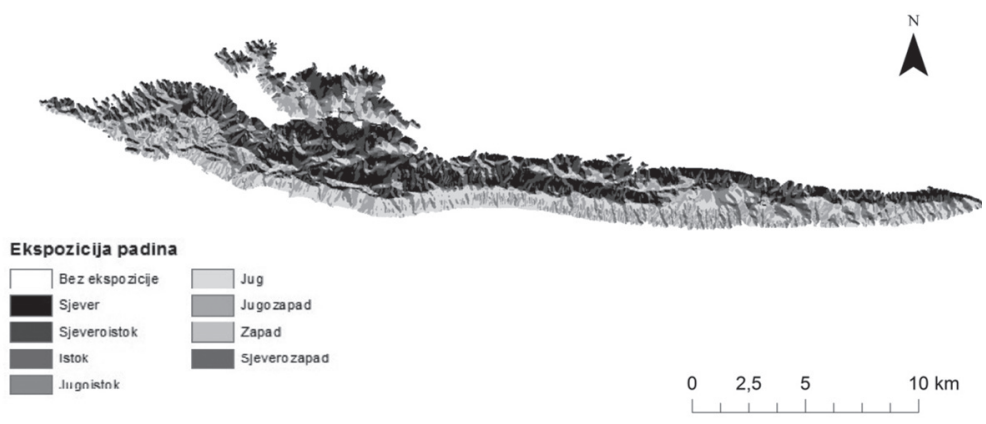

Slika 8. Karta ekspozicije padina otoka Hvara (Izradeno prema CGIAR Konzorcij za Prostorne Informacije, 2008) 


\section{PEDOLOŠKA I PEDOGEOGRAFSKA OBILJEŽJA OTOKA HVARA}

Analiza tala otoka Hvara provedena je iz aspekta njihovih svojstava, obilježja i proizvodnog potencijala u poljodjelstvu te iz aspekta njihove prostorne distribucije. Pedološka i pedogeografska analiza potrebna je za dodjeljivanje korektivnih bodova u drugoj fazi geoekološkog vrednovanja krajolika otoka Hvara s obzirom na poljodjelsko iskorištavanje.

$\mathrm{Na}$ otoku Hvaru javlja se 7 tipova tala: antropogena flišnih i krških sinklinala i koluvija, antropogena na kršu, vapnenačko-dolomitna crnica, lesivirana i tipična duboka crvenica, rendzina na dolomitu i vapnencu, rendzina na trošini vapnenca te smeđe na vapnencu (Slika 9). Najveću površinu i udio u ukupnoj površini otoka Hvara zauzima smeđe tlo na vapnencu (Tablica 6). Proizvodni potencijal smeđih tala na vapnencu u slučaju otoka Hvara je nizak (Husnjak, 2014). Drugi najzastupljeniji tip tla je antropogeno tlo na kršu koje pokriva $70,83 \mathrm{~km}^{2}$, odnosno $23,78 \%$ površine otoka (Tablica 6). Antropogena tla na kršu, kao i antropogena tla flišnih i krških sinklinala i koluvija $\left(13,75 \mathrm{~km}^{2} ; 4,62 \%\right)$, karakterizira umjereno visok proizvodni potencijal ako se navodnjavaju, i to bez obzira na trenutni stupanj fizikalnih, kemijskih i bioloških svojstava. Porastom stupnja povoljnosti tih svojstava raste i stupanj njihova proizvodnog potencijala koji je ionako već visok (Husnjak, 2014). Mnogo su manje zastupljeni rendzina na dolomitu i vapnencu $\left(19,95 \mathrm{~km}^{2}\right.$; $6,7 \%)$, vapnenačko-dolomitna crnica $\left(14,21 \mathrm{~km}^{2} ; 4,77 \%\right)$ te rendzina na trošini vapnenca $\left(9,57 \mathrm{~km}^{2} ; 3,21 \%\right)$ (Tablica 6). Proizvodni potencijal vapnenačko dolomitne crnice vrlo je nizak, zbog čega nije pogodna za poljodjelstvo. Rendzine na dolomitu i vapnencu te na trošini vapnenca imaju vrlo nizak proizvodni potencijal zbog male dubine, skeletnosti i velikih nagiba. Rendzina je vrlo podložna eroziji vodom, a obrada tla u poljodjelske svrhe potencira pojavu erozijskih procesa (Husnjak, 2014). Lesivirana i tipična duboka crvenica, s osrednje visokim proizvodnim potencijalom (Husnjak, 2014), zanemarivo je zastupljena $\left(1,06 \mathrm{~km}^{2} ; 0,36 \%\right)$ (Tablica 6).

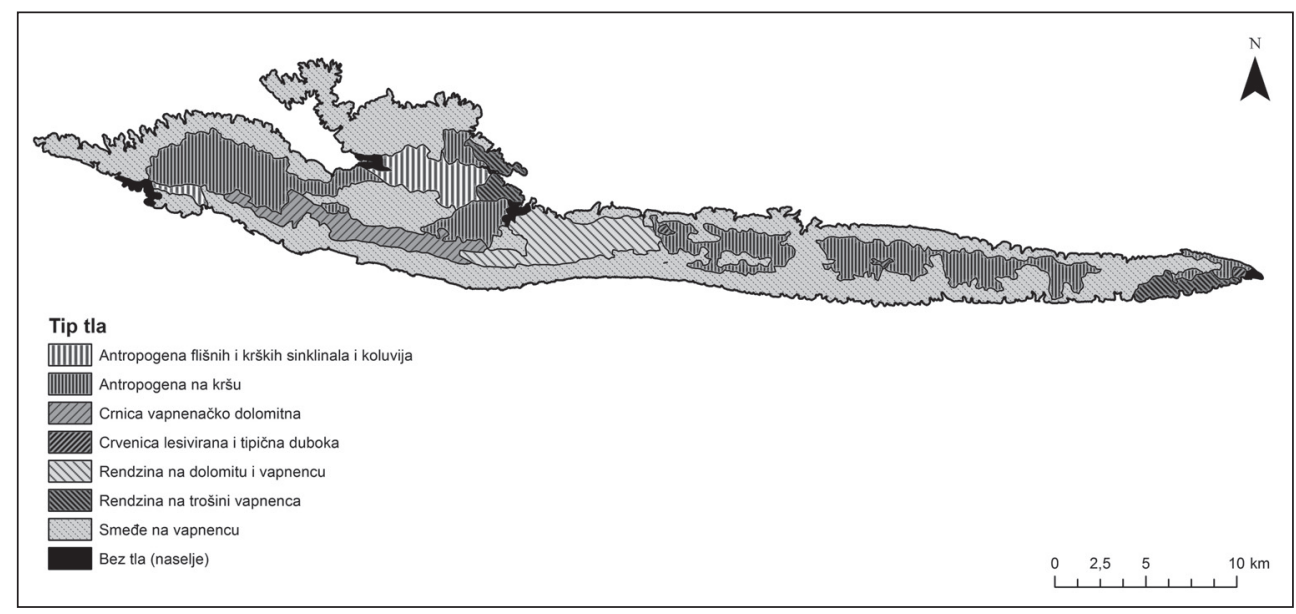

Slika 9. Pedološka karta otoka Hvara (Izradeno prema Digitalna pedološka karta RH 1:300 000, 2014) 
Tablica 6. Tipovi tala otoka Hvara s površinama i udjelima u ukupnoj površini

\begin{tabular}{|l|c|c|}
\hline \multicolumn{1}{|c|}{ Tip tla } & Površina $\mathbf{( k m}^{2} \mathbf{)}$ & $\begin{array}{c}\text { Udio u ukupnoj } \\
\text { površini (\%) }\end{array}$ \\
\hline Antropogena flišnih i krških sinklinala i koluvija & 13,75 & 4,62 \\
\hline Antropogena na kršu & 70,83 & 23,78 \\
\hline Crnica, vapnenačko-dolomitna & 14,21 & 4,77 \\
\hline Crvenica lesivirana i tipična duboka & 1,06 & 0,36 \\
\hline Rendzina na dolomitu i vapnencu & 19,95 & 6,7 \\
\hline Rendzina na trošini vapnenca & 9,57 & 3,21 \\
\hline Smeđe na vapnencu & 164,98 & 55,38 \\
\hline Bez tla (naselje) & 3,56 & 1,18 \\
\hline \multicolumn{1}{|c|}{ Ukupno } & 297,86 & 100 \\
\hline
\end{tabular}

\section{GEOEKOLOŠKO VREDNOVANJE OTOKA HVARA S ASPEKTA POLJODJELSKE VALORIZACIJE}

U prvoj fazi (faza predvrednovanja) računaju se temeljne ekovrijednosti krajolika kao funkcija određenih morfometrijskih i morfodinamskih obilježja reljefa krajolika. Ta obilježja su hipsometrija, nagibi padina, vertikalna raščlanjenost reljefa te mobilnost padina (Tablica 3). Koncept temeljne ekovrijednosti temelji se na premisi da će područje (u slučaju geoekološkog vrednovanja jedinična površina) imati veću temeljnu ekovrijednost ako ga karakterizira mala nadmorska visina, blagi nagibi, mala vertikalna raščlanjenost te velika stabilnost padina. Povećanjem iznosa navedenih morfometrijskih parametara reljefa te mobilnosti padina, temeljna ekovrijednost se smanjuje.

$\mathrm{U}$ ovom radu određeno je po 6 kategorija za svaki reljefni element bodovanja. Za najpovoljniju kategoriju svih spomenutih morfometrijskih parametara reljefa te mobilnosti padina dodijeljeno je 25 bodova. Svakoj sljedećoj kategoriji nakon najpovoljnije, dodijeljen je manji broj bodova. Ako se jedinična površina nalazi u prvoj kategoriji (najpovoljnijoj) određenog elementa bodovanja, dodijelit će joj se 25 bodova, a ako se nalazi u drugoj kategoriji dodijelit će joj se 20,8 bodova. Razlika između bodova je količnik najvećeg broja bodova i ukupnog broja kategorija pojedinog elementa bodovanja, a iznosi 4,2. Za svaku sljedeću kategoriju taj broj je oduzet da bi se dobio broj bodova koji se dodjeljuje. Tako jedinična površina može imati temeljnu ekovrijednost u iznosu od maksimalno 100 bodova, odnosno, minimalno 16,8 bodova (Tablica 7).

Nakon obavljenog predvrednovanja dobivene temeljne ekovrijednosti krajolika (podijeljenog na jedinične površine) kreću se od 33,2 do 95,8 te su klasificirane u 10 kategorija jednakog intervala (Slika 3). Ni jedna jedinična površina nije dobila maksimalan broj bodova (100), budući da na otoku kategorija vertikalne raščlanjenosti $0-5 \mathrm{~m} / \mathrm{km}^{2}$ nije uopće zastupljena. 
Tablica 7. Bodovni sustav predvrednovanja

\begin{tabular}{|c|c|c|c|c|c|c|c|c|}
\hline Kat. & $\begin{array}{c}\text { Hipsometrija } \\
(\mathbf{m})\end{array}$ & Bod & $\begin{array}{c}\text { Nagibi } \\
\left({ }^{\circ}\right)\end{array}$ & Bod & $\begin{array}{c}\text { Vert. raščl. } \\
\left(\mathbf{m} / \mathbf{k m}^{2}\right)\end{array}$ & Bod & $\begin{array}{c}\text { Mobilnost } \\
\text { padina }\end{array}$ & Bod \\
\hline $\mathbf{1 .}$ & $0-100$ & 25,0 & $0-2$ & 25,0 & $0-5$ & 25,0 & Stabilno & 25,0 \\
\hline $\mathbf{2 .}$ & $100-200$ & 20,8 & $2-5$ & 20,8 & $5-30$ & 20,8 & $\begin{array}{c}\text { spiranje, } \\
\text { puženje tla }\end{array}$ & 20,8 \\
\hline $\mathbf{3 .}$ & $200-300$ & 16,7 & $5-12$ & 16,7 & $30-100$ & 16,7 & $\begin{array}{c}\text { jača erozija, } \\
\text { intenzivno } \\
\text { spiranje }\end{array}$ & 16,7 \\
\hline $\mathbf{4 .}$ & $300-400$ & 12,5 & $12-32$ & 12,5 & $100-300$ & 12,5 & $\begin{array}{c}\text { veoma jaka } \\
\text { erozija }\end{array}$ & 12,5 \\
\hline $\mathbf{5 .}$ & $400-500$ & 8,3 & $32-55$ & 8,3 & $300-800$ & 8,3 & $\begin{array}{c}\text { odnošenje } \\
\text { materijala }\end{array}$ & 8,3 \\
\hline $\mathbf{6 .}$ & $>500$ & 4,2 & $>55$ & 4,2 & $>800$ & 4,2 & $\begin{array}{c}\text { urušavanje, } \\
\text { odroni }\end{array}$ & 4,2 \\
\hline
\end{tabular}

Jedinične površine obilježene najvećim iznosima temeljnih ekovrijednosti nalaze se u reljefnim cjelinama Hvarskog polja te pobrđa Rudine-Kabal koje su uglavnom obilježene niskom nadmorskom visinom, blagim nagibima, malom vertikalnom raščlanjenošću te stabilnošću padina. Ipak, na nižoj razini postoji određena prostorna diferencijacija. Središnji dio Hvarskog polja sastavljen je od jediničnih površina koje pripadaju vrijednosno najjačoj kategoriji. Jedinične površine ruba Hvarskog polja, s druge strane, karakteriziraju nešto niži iznosi temeljnih ekovrijednosti iako su to i dalje komparativno visoke vrijednosti. Isti je slučaj i s pobrđem Rudine-Kabal. Središnji zaravnjeni dio obilježen je višim iznosima temeljnih ekovrijednosti za razliku od ruba pobrđa, što je uvjetovano prvenstveno razlikama u nagibima i mobilnosti padina. Relativno visoke temeljne ekovrijednosti također imaju i krajnji istočni te zapadni kraj otoka kao i zaravan Plame (Slika 3).

Jedinične površine obilježene najnižim ekovrijednostima nalaze se u centralnom dijelu otočnog hrpta kojeg karakteriziraju visoka nadmorska visina, veliki nagibi, velika vertikalna raščlanjenost te velika mobilnost padina. Ostatak hrpta karakteriziraju uglavnom jedinične površine obilježene vrijednostima koje pripadaju središnjim kategorijama temeljnih ekovrijednosti. Izuzetak su krajnji istočni i zapadni dio otoka te zaravan Plame (Slika 3). Uzevši u obzir podjednak utjecaj reljefa na velik broj načina korištenja prostora (osim onih vrlo specifičnih koji zahtijevaju potpuno suprotni princip dodjeljivanja većeg ili manjeg broja bodova, poput skijališnog turizma ili škrapinga u krškim prostorima) nameće se zaključak da je potrebno dodatno vrednovati odabrane elemente da bi se potpuno prilagodili pojedinačnom načinu korištenja prostora, u ovom slučaju poljodjelskom. Tu nastupa druga faza (faza vrednovanja) u kojoj se, na temelju odabranih prirodnih i društvenih elemenata, jediničnim površinama dodjeljuju korektivni bodovi pomoću kojih se ocjenjuje pogodnost obilježja pojedinog (prirodnog ili društvenog) elementa unutar jedinične površine, a specifično za odabrani način korištenja - u ovom slučaju poljodjelstvo. Odabrani prirodni elementi su nagibi padina, mobilnost padina, 
Soc. ekol. Zagreb, Vol. 25 (2016.), No. 3

B. R. Čirjak i M. Mamut: Geoekološko vrednovanje reljefa otoka Hvara s aspekta poljodjelske valorizacije

\begin{tabular}{|c|c|c|c|c|c|c|c|c|c|}
\hline & मीं & $\forall$ & $n$ & $\sim$ & - & $Y^{\prime}$ & & & \\
\hline 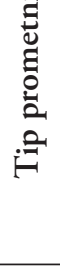 & $\stackrel{2}{*}$ & 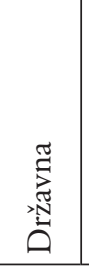 & 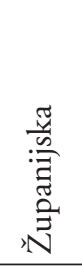 & 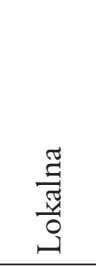 & 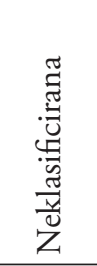 & 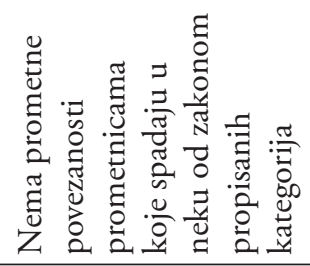 & & & \\
\hline & فे & \multicolumn{2}{|c|}{$\stackrel{0}{-}$} & $Y_{Y}^{+}$ & $\wedge$ & \multicolumn{2}{|l|}{$m$} & $\forall$ & $x$ \\
\hline $\begin{array}{l}\frac{\pi}{3} \\
\stackrel{2}{1}\end{array}$ & $\stackrel{2}{\because}$ & \multicolumn{2}{|c|}{ 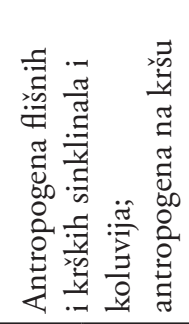 } & 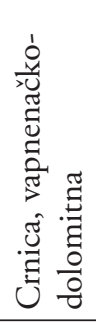 & 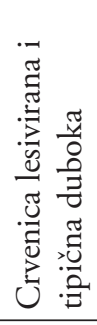 & \multicolumn{2}{|l|}{ 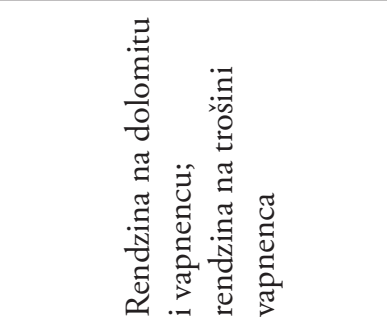 } & 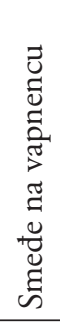 & 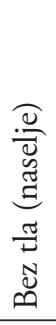 \\
\hline \multirow{2}{*}{ 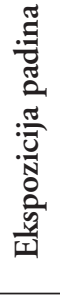 } & فं & 0 & $\infty_{1}$ & $n$ & $N$ & $n$ & $n$ & 0 & \\
\hline & 蔦 & 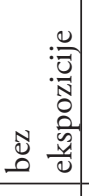 & Z & $\begin{array}{c}\text { z } \\
\text { 穵 } \\
\end{array}$ & 더 & $\geqslant$ & $\begin{array}{l}8 \\
\text { w } \\
\text { जी }\end{array}$ & $n$ & \\
\hline \multirow{2}{*}{ 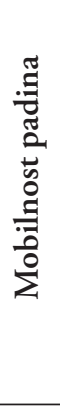 } & कीं & in & $\Upsilon$ & $n$ & $\stackrel{\circ}{7}$ & $x$ & & & \\
\hline & $\stackrel{\frac{n}{\hat{0}}}{0}$ & 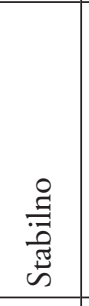 & 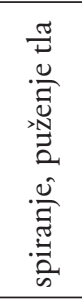 & 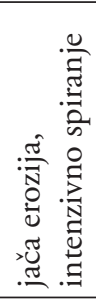 & 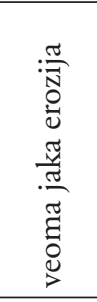 & 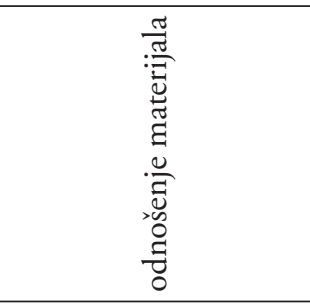 & & & \\
\hline \multirow{2}{*}{ 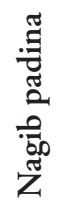 } & అ. & in & $m$ & $p$ & $\widehat{\Upsilon}$ & $x$ & & & \\
\hline & 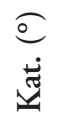 & กิ & $\tilde{i}$ & $\stackrel{7}{\stackrel{7}{n}}$ & 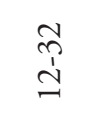 & $\widetilde{N}$ & & & \\
\hline
\end{tabular}


ekspozicija padina te tip tla, a od društvenih elemenata tip prometnice (Tablica 8). Ove morfometrijske varijable najbolje određuju reljefnost područja (karakteristike oblika i dimenzije reljefa) što je predmet istraživanja u radu. Uz reljefnost, za planiranje poljodjelstva neizostavani su podaci o plodnosti tla i dostupnosti.

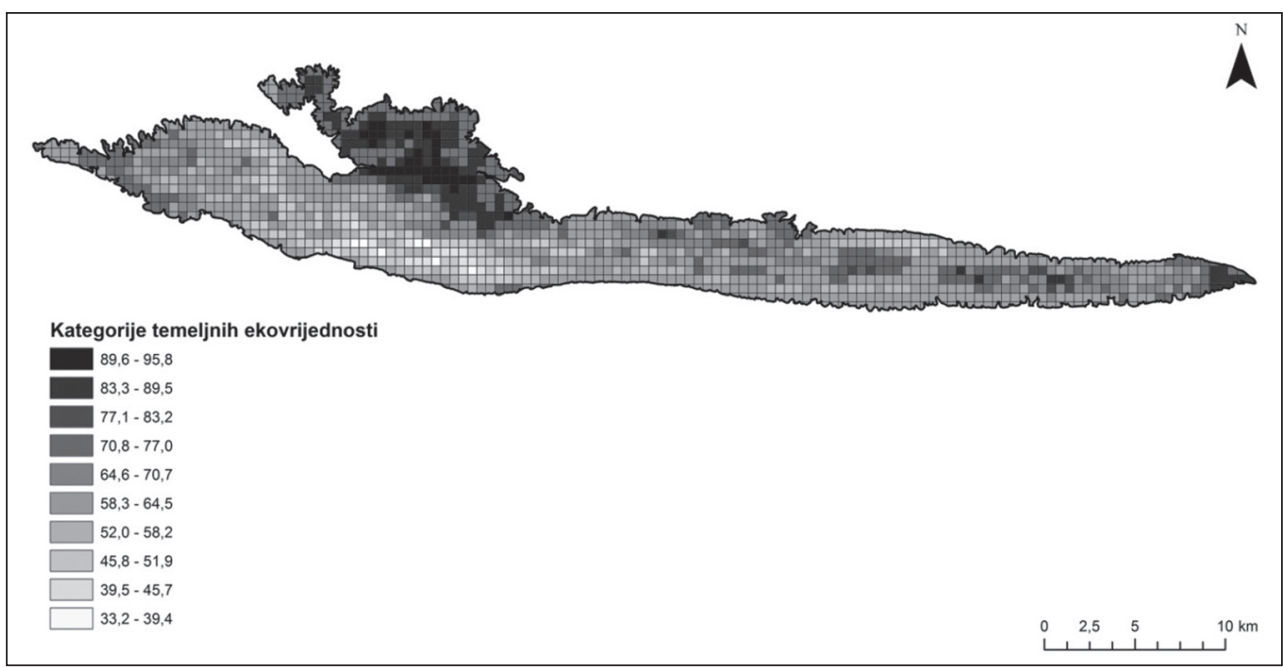

Slika 10. Kategorije temeljnih ekovrijednosti otoka Hvara (Izradeno prema CGIAR Konzorcij za Prostorne Informacije, 2008)

Korektivni bodovi se oduzimaju ili pridodaju startni bodovima dobivenim predvrednovanjem. $\mathrm{Sb}+/-\mathrm{Kb}=\mathrm{Vr}$ ( $\mathrm{Sb}$ su startni bodovi, $\mathrm{Kb}$ su korektivni bodovi, $\mathrm{Vr}$ je ukupan broj bodova). $\mathrm{Na}$ osnovu ukupnog broja bodova jedinične su površine razvrstane u 10 bonitetnih kategorija koje su u rasponu od izrazito nepogodnog terena (0. bonitetna kategorija) do najurjednijeg terena (9. bonitetna kategorija) (Tablica 9) i kartografski su prikazane (Slika 4). Izrađena je i statistika geoekološkog vrednovanja (Tablica 10).

Tablica 9. Bonitetne kategorije geoekološkog vrednovanja

\begin{tabular}{|c|l|c|}
\hline Bonitetna kategorija & \multicolumn{1}{|c|}{ Razred } & Broj bodova \\
\hline 9 & najvrjedniji tereni & $91-100$ \\
\hline 8 & veoma vrijedni tereni & $81-90$ \\
\hline 7 & pretežno vrijedni tereni & $71-80$ \\
\hline 6 & relativno manje vrijedni tereni & $61-70$ \\
\hline 5 & pretežno manje vrijedni tereni & $51-60$ \\
\hline 4 & relativno nepogodni tereni & $41-50$ \\
\hline 3 & pretežno nepogodni tereni & $31-40$ \\
\hline 2 & nepogodni tereni & $21-30$ \\
\hline 1 & vrlo nepogodni tereni & $11-20$ \\
\hline 0 & izrazito nepogodni tereni & $1-10$ \\
\hline
\end{tabular}

Izvor: Bognar, 1990. 


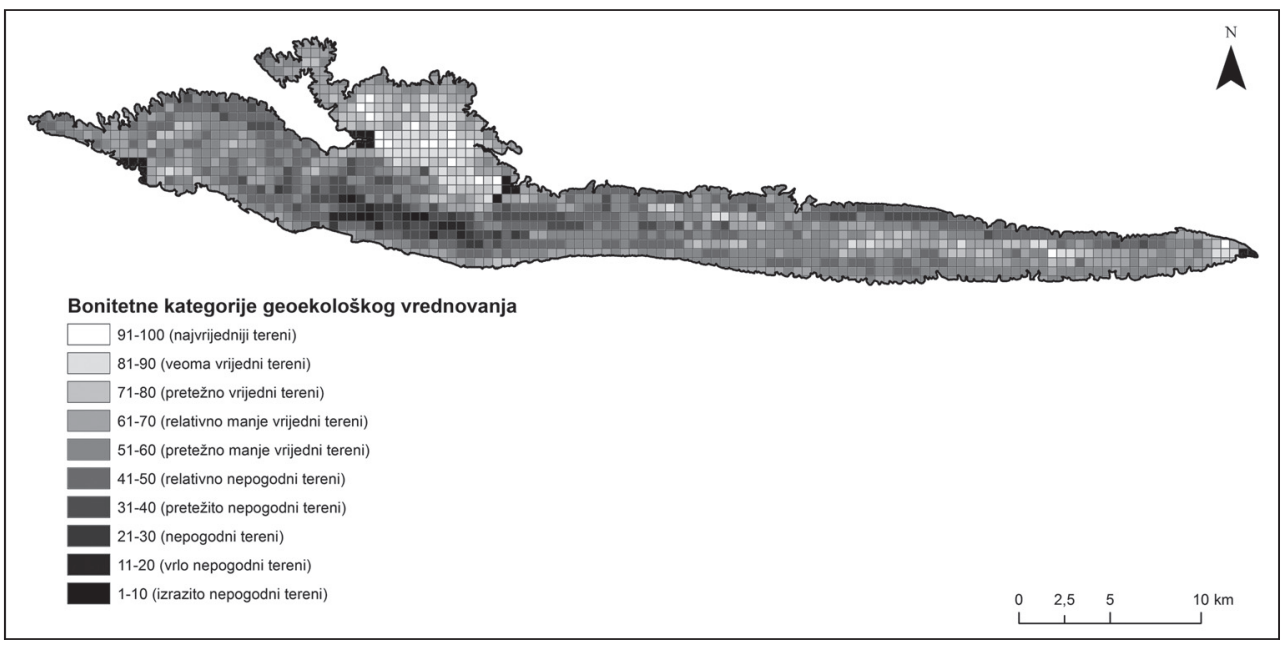

Slika 11. Bonitetne kategorije pogodnosti terena za poljodjelsko iskorištavanje (Izradeno prema CGIAR Konzorcij za Prostorne Informacije, 2008; Digitalna pedološka karta RH, 2014; SRPJ, 2015)

Tablica 10. Broj jediničnih površina i ukupna površina u bonitetnim kategorijama

\begin{tabular}{|l|c|c|c|c|}
\hline \multicolumn{1}{|c|}{ Bonitetne kategorije } & $\begin{array}{c}\text { Broj } \\
\text { jediničnih } \\
\text { površina }\end{array}$ & $\begin{array}{c}\text { Udio u } \\
\text { ukupnom } \\
\text { broju } \\
\text { jediničnih } \\
\text { površina } \\
(\%)\end{array}$ & $\begin{array}{c}\text { Površina } \\
\left(\mathbf{k m}^{2}\right)\end{array}$ & $\begin{array}{c}\text { Udio u } \\
\text { ukupnoj } \\
\text { površini } \\
(\%)\end{array}$ \\
\hline 91-100 (najvrjedniji tereni) & 17 & 1,2 & 4,3 & 1,4 \\
\hline $81-90$ (veoma vrijedni tereni) & 63 & 4,4 & 15,5 & 5,2 \\
\hline $71-80$ (pretežno vrijedni tereni) & 117 & 8,2 & 24,9 & 8,4 \\
\hline 61-70 (relativno manje vrijedni tereni) & 349 & 24,5 & 66 & 22,1 \\
\hline 51-60 (pretežno manje vrijedni tereni) & 412 & 28,9 & 86,3 & 28,9 \\
\hline 41-50 (relativno nepogodni tereni) & 322 & 22,6 & 66,3 & 22,2 \\
\hline $31-40$ (pretežno nepogodni tereni) & 90 & 6,3 & 22,4 & 7,5 \\
\hline 21-30 (nepogodni tereni) & 18 & 1,3 & 4,4 & 1,5 \\
\hline $11-20$ (vrlo nepogodni tereni) & 12 & 0,8 & 3 & 1 \\
\hline $1-10$ (izrazito nepogodni tereni) & 25 & 1,8 & 4,7 & 1,6 \\
\hline Ukupno & 1425 & 100 & 298 & 100 \\
\hline
\end{tabular}




\section{REZULTATI GEOEKOLOŠKOG VREDNOVANJA OTOKA HVARA IZ ASPEKTA POLJODJELSKE VALORIZACIJE}

Detaljni rezultati vrednovanja prikazani su u Tablici 10 i na Slici 4, no zbog lakšeg planiranja namjene površina dio podataka je objedinjen. Geoekološko vrednovanje otoka Hvara iz aspekta poljodjelske valorizacije pokazalo je da se čak $86 \%$ jediničnih površina (1228), odnosno $85 \%$ površine otoka Hvara $\left(253,1 \mathrm{~km}^{2}\right)$ nalazi u bonitetnim kategorijama do 70 bodova, odnosno u kategorijama od izrazito nepogodnih terena do relativno manje vrijednih terena (Tablica 10). Samo 14\% jediničnih površina (197), odnosno 15\% površine otoka Hvara $\left(44,9 \mathrm{~km}^{2}\right)$ nalazi se u kategorijama s više od 70 bodova. To su kategorije označene kao pretežno vrijedni tereni, veoma vrijedni tereni te najurjedniji tereni. Drugim riječima, samo $15 \%$ površine otoka Hvara pogodno je za kvalitetno i isplativo poljodjelstvo (Tablica 10) čime je potvrđena H1. Budući da sve poljodjelske kulture nemaju iste zahtjeve, geoekološko vrednovanje provedeno na temelju detaljne geomorfološke analize predstavlja temelj multidisciplinarnom istraživanju u cilju kompleksnog gospodarenja prirodnim okolišem. Provođenje interdisciplinarnog istraživanja definiralo bi pojedine prostore za određene kulture. Zahvaljujući malim nagibima, velikoj stabilnosti padina, povoljnoj ekspoziciji, plodnom tlu te postojećoj mreži prometnica, Hvarsko polje najpovoljniji je dio otoka Hvara za poljodjelsku valorizaciju. Sve jedinične površine Hvarskog polja prema navedenim kriterijima relativnog vrednovanja reljefa iz aspekta poljodjelske valorizacije razlikuju se po dobivenom broju bodova te pripadaju kategorijama pretežno vrijednih terena, veoma vrijednih terena te najurjednijih terena za poljodjelsko iskorištavanje (Slika 4). Razvrstavanje u prve tri kategorije potvrđuje $\mathrm{H} 2$.

Izuzetno pogodnom za poljodjelsku valorizaciju otoka Hvara se pokazala i zaravan Plame, prvenstveno zbog malih nagiba, stabilnosti padina, povoljne ekspozicije, postojanja plodnog tla (antropogeno na kršu) te cestovne povezanosti (državna cesta) te je time rezultat bolji od očekivanog u H3. Sličnih povoljnih karakteristika su i pobrđe Rudine-Kabal te nešto manje zapadni dio otočnog grebena (Slika 4).

Najnepogodniji prostor otoka Hvara za poljodjelsku valorizaciju je središnji dio otočnog grebena koji je još u fazi predvrednovanja dobio vrlo mali broj bodova zbog visokih nadmorskih visina, velikih nagiba, velikih iznosa vertikalne raščlanjenosti te izražene mobilnosti padina. Korektivni bodovi dodatno su umanjili temeljnu vrijednost prostora zbog velikog nagiba i mobilnosti padina te nepovoljnog tla i slabe dostupnosti. Dobiveni podaci potvrđuju H4. Postojanje tla ili prometnica ne može nadomjestiti nepogodnost terena koja proizlazi iz fizičkih karakteristika istog (nagibi, ekspozicija) (Slika 4).

\section{ZAKLJUČAK}

Provedenim vrednovanjem reljefa otoka Hvara potvrdeno je da su za geoekološka istraživanja neophodne detaljne geomorfološke analize prostora.

Posebno se to odnosi na geoekološko istraživanje reljefa kao veze litosfere, pedosfere, atmosfere, hidrosfere i biosfere. Istraživanje reljefa podrazumijeva njegovu detaljnu geomorfološku analizu te je neophodno provesti geomorfološko kartiranje i analizu 
egzomorfoloških procesa, morfometrijske i morfostrukturne analize koje upotpunjuju potrebnu bazu podataka na temelju kojih se vrši vrednovanje. Od provedenih morfometrijskih i morfostrukturnih analiza za potrebe geoekološkog vrednovanja iz aspekta poljodjelske valorizacije iznimno korisnima pokazale su se analiza visinskih odnosa (hipsometrija), nagiba i mobilnosti padina te vertikalne raščlanjenosti reljefa na temelju kojih je provedeno predvrednovanje i izračunate temeljne ekovrijednosti. Poznavajući zahtjeve definiranog oblika aktivnosti (poljodjelstvo) precizirani su kriteriji vrednovanja. Ekspozicija padina, tip tla i prometna povezanost korišteni su kao korektivni elementi vrednovanja u geoekološkom vrednovanju reljefa otoka Hvara iz aspekta njegove fizičke pogodnosti za poljodjelsku valorizaciju. Odabir korektivnih elemenata određen je prema zahtjevima koje postavlja poljodjelska aktivnost.

Vrednovanje reljefa otoka Hvara provedeno je prema temeljnim postavkama metode relativnog vrednovanja reljefa, koja je djelomično prerađena i prilagođena zahtjevima zadatka i specifičnostima vrednovanog reljefa. Provedeno vrednovanje uputilo je na vrijedne i potencijalno vrijedne dijelove reljefa otoka te na neke ograničavajuće elemente zbog kojih pojedine dijelove otoka nije moguće poljodjelski valorizirati bez dodatnih zahvata u prostoru.

Geoekološko vrednovanje reljefa otoka Hvara iz aspekta poljodjelske valorizacije uvjetno je potvrdilo hipoteze postavljene u radu. Najveći dio otoka (čak $85 \%$ površine) vrednovanjem je pokazao vrijednosti od kategorije izrazito nepogodnih terena do relativno manje vrijednih terena.

Najpovoljniji dio prostora otoka Hvara za poljodjelsku valorizaciju je reljefna cjelina Hvarskog polja gdje su svi kriteriji predvrednovanja (mala nadmorska visina, mali nagibi, stabilnost padina) i vrednovanja (povoljna ekspozicija, plodno tlo, postojanje cestovne mreže) visokih bodovnih vrijednosti. Zaravan Plame, dio otočnog grebena, pokazalo je vrlo povoljne vrijednosti za poljodjelsku valorizaciju. Postojanje velikih površina antropogenog tla na navedenim prostorima posljedica je višestoljetne prepoznatljivosti i poljodjelskog korištenja ovih dijelova otoka.

Središnji dio otočnog grebena ocijenjen je kao najnepovoljniji dio otoka Hvara za poljodjelsku valorizaciju. Nepovoljnost te reljefne cjeline posljedica je velikih nadmorskih visina, nagiba, vertikalne raščlanjenosti i slabe prometne dostupnosti.

\section{LITERATURA}

Bognar, A. (1990). Geomorfološke i inženjersko-geomorfološke osobine otoka Hvara i ekološko vrednovanje reljefa. Geografski glasnik, 52(1): 49-65.

Bognar, A. (2001). Geomorfološka regionalizacija Hrvatske. Acta Geographica Croatica, 34: 7-29.

CGIAR Konzorcij za Prostorne Informacije (2008). SRTM 90m Digital Elevation Database q v4.1. URL: http://www.cgiar-csi.org/data/srtm-90m-digital-elevation-database-v 41 (20.11.2014.)

Crkvenčić, I. i Malić, A. (1988). Agrarna geografija. Zagreb: Školska knjiga. 
Digitalna pedološka karta RH (2014). URL: http://pedologija.com.hr/karte.htm (20.11.2014.)

Džaja, K. (2003). Geomorfološke značajke Dugog otoka. Geoadria, 8(2): 5-44.

Herak, M. (1991). Dinaridi - mobilistički osvrt na genezu i strukturu. Acta Geologica, 21(2): 35-111.

Herak, M. (1999). A New Concept of Geotectonics of the Dinarides. Geologia Croatica, 52(1): 83-98.

Husnjak, S. (2014). Sistematika tala Hrvatske. Zagreb: Hrvatska Sveučilišna naklada.

Lozić, S. (1995). Vertikalna raščlanjenost reljefa kopnenog dijela Republike Hrvatske. Acta Geographica Croatica, 30: 17-28.

Lozić, S., Šiljeg, A. i Krklec, K. (2013). Morfometrijske značajke otoka Visa. Naše more, 60(5-6): 110-117.

Magaš, D. (2013). Geografija Hrvatske. Zagreb: Meridijani.

Mamut, M. (1999). Geomorfološke značajke reljefa otoka Ugljana i otoka Pašmana i njegovo geoekološko vrednovanje. Magistarski rad. Zagreb: Sveučilište u Zagrebu, Geografski odsjek Prirodoslovno-matematičkog fakulteta

Mamut, M. (2010a). Primjena metode relativnog vrednovanja reljefa na primjeru otoka Rave (Hrvatska). Naše more, 57(5-6): 260-271.

Mamut, M. (2010b). Geoekološki i turistički potencijal krajolika otoka Ugljana. Socijalna ekologija, 19(3): 247-271.

Mamut, M. (2010c). Geoekološko vrjednovanje reljefa otoka Pašmana. Geoadria, 15(2): 241- 267.

Pahernik, M. (2007). Digitalna analiza padina otoka Raba. Geoadria, 12(1): 3-22.

Saletto Janković, M. (1994). The role of geomorphological research in geoecology. Acta Geographica Croatica, 29(1): 37-44.

Summerfield, M. A. (1991). Global Geomorphology. An introduction to the Study of Landforms. New York: Harlow, Longman.

SRPJ - Središnji registar prostornih jedinica. (2015). Državna geodetska uprava. URL: http://geoportal.dgu.hr/ (22.09.2015.) 


\title{
GEOECOLOGICAL ASSESSMENT OF THE RELIEF OF THE ISLAND OF HVAR FROM THE PERSPECTIVE OF AGRICULTURAL VALORISATION
}

\author{
Barbara Ruža Čirjak and Marica Mamut
}

\begin{abstract}
Geoecological assessment of the relief of the island of Hvar for the purpose of agricultural development has been conducted using the method of relative valorisation of the relief, modified to suit this particular terrain and the ways in which it is used. The valorisation is based on previously conducted geomorphological analysis, as well as the analysis of the physical suitability of island's relief (hypsometry, vertical dissection, exposition, slope stability). In addition, the suitability of the terrain and availability of certain parts of the island for agricultural activities were also taken into consideration.

The main aim of this research was to determine which parts of the island of Hvar are suitable, or potentially suitable, from the perspective of agriculture. The results reveal that only $15 \%$ of the area of the island of Hvar is suitable for marketable sustainable agriculture. Most appropriate parts of the island of Hvar are Hvarsko polje (Hvar's plain), Plame plain and Rudine-Kabal hills. The main limitations to agrarian valorisation of certain parts of the island of Hvar are: altitude, significant vertical dissection, and a high degree of tilt that increases the mobility of slopes. The limitations for the agrarian use of this area are particularly prominent in the central part of the island's reef, which is therefore marked as the least suitable area for agrarian valorisation. The existence of suitable terrain or roads cannot substitute for the unsuitability of terrain as the result of its physical characteristics (slopes, exposition).
\end{abstract}

Key words: Hvar island, geoecological assessment, method of relative assessment of relief, agricultural valorisation

\section{GEOÖKOLOGISCHE AUSWERTUNG DES RELIEFS DER INSEL HVAR AUS DEM GESICHTSPUNKT DER LANDWIRTSCHAFTLICHEN ERSCHLIEßUNG

\author{
Barbara Ruža Čirjak und Marica Mamut
}

\section{Zusammenfassung}

Die geö̈kologische Auswertung des Reliefs der Insel Hvar zum Zweck der Entwicklung der Landwirtschaft wurde mit Hilfe der Methode der relativen Reliefauswertung durchgeführt, mit Anpassung an die Besonderheiten des Raumes und dessen Nutzung. Die Auswertung beruht auf der vorherigen geomorphologischen Analyse und der Analyse der physischen Eignung des Reliefs der Insel (Hypsometrie, vertikale Gliederung, Exposition, Hangstabilität), sowie der Bodeneignung und Erreichbarkeit einiger Teile der Insel für landwirtschaftliche Zwecke.

Das Ziel der durchgeführten Forschung war es festzustellen, welche Teile der Insel Hvar landwirtschaftlich geeignet oder potentiell geeignet sind. Die Resultate haben gezeigt, dass nur 15\% der Fläche der Insel Hvar auf Dauer für eine marktorientierte Landwirtschaft geeignet sind. Die am besten geeigneten Teile der Insel Hvar sind Hvarsko polje, Plame Plateau und Rudine-Kabal-Gebirge. Die Hauptbegrenzungsfaktoren für die Agrarerschließung einiger Teile der Insel Hvar sind: die Höhenlage, eine starke vertikale Gliederung und große Neigungswinkel, die die Hangmobilität erhöhen. Die begrenzten Möglichkeiten für eine landwirtschaftliche Nutzung dieses Raumes sind besonders im zentralen Teil des Bergrückens der Insel Hvar ausgeprägt, daher wurde er für die landwirtschaftliche Erschließung für am wenigsten geeignet befunden. Das Bestehen vom geeigneten Boden oder Verkehrswegen kann die aus physischen Eigenschaften resultierende Unangemessenheit des Geländes (Neigungswinkel, Exposition) nicht ersetzen.

Schlüsselwörter: Insel Hvar, geoökologische Auswertung, Methode der relativen Reliefauswertung, landwirtschaftliche Erschließung 